\title{
REPRODUCTION AND CHEMICAL STERILIZATION OF THE EYE GNAT, HIPPELATES PUSIO LOEW
}

By

PAUL HENRY SCHWARTZ, JR.

\begin{abstract}
A DisSERTATION PRESENTED TO THE GRADUATE COUNCIL OF THE UNIVERSTTY OF FLORIDA

IN PARTLAL FULFILLMENT OF THE REQUIREMENTS FOR THE DEGREE OF DOCTOR OF PHILOSOPHY
\end{abstract}

UNIVERSITY OF FLORIDA

August, 1964 


\section{ACENOWLBDGMIANPS}

I would like to thank Dr. John T. Creighton, Head, Department of Entomology, who served as my chairman of the Supervisory Comnittee. I sincerely appreclate his encouragement and advice during the various aspects of the research.

Much appreciation also goes to Drs. F. S. Blanton, W. W. Smith, C. N. Smith, and A. Carr who served as members of the Supervisory Coumittee.

Without the kindness of Dr. Carroll N. Smlth, Investigations Leader, and other members of the Laboratory of Insects Affecting Man and Animals, Intomology Research Division, United States Department of Agriculture; this study could not have been earried out. Much appreciation also goes to Dr. G. C. LaRrecque, Dr. D. ‥ Weldhas, Dr. D. A. Dame, Dr. P. B. Morgan, Mr. J. B. Gahan, Mr. I. H. Gllbert, and $\mathrm{Mr}$. C. Lofgren for their interest and encouragement throughout my course of study.

I am indebted to my wife Mary for her patience and understanding throughout the scope of this project.

Th1s research was sponsored in part by the Insects Affecting Man and Animals, Intomology Research Division, United States Department of Agriculture, as a cooperative project with the Department of Entomology, University of Florida. 
TABLE OF CONTENTS

Page

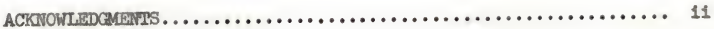

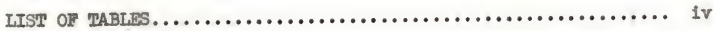

IIST OF ILUUSTRATIONS. $\ldots \ldots \ldots \ldots \ldots \ldots \ldots \ldots \ldots \ldots \ldots \ldots \ldots \ldots \ldots \ldots$

INTRODUCTION. .................................... 1

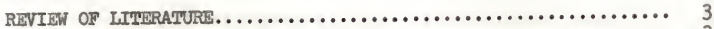

Organs of Reproduction in Insects.................... 3

Chemosterilization of Insects...................... 6

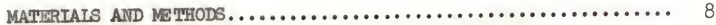

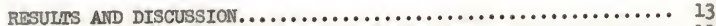

Anatomy of the Internal Reproductive System............ 13

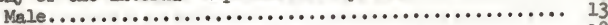

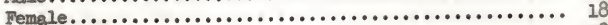

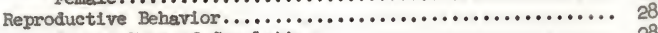

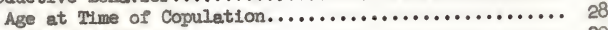

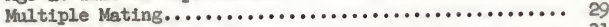

Testicular Maturation........................ 31

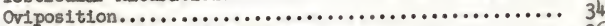

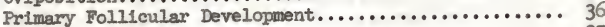

Chemoster1l1zat1on.............................. 37

Preliminary Tests.......................... 37

Sterility and Toxicity....................... 38

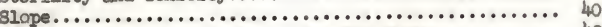

Effect of Chemosterllants on the Two Sexes.......... 42

Befects of Chemosterilants on the Reproductive System...... 43

Histopathology of Male Conads.................. 43

Histopathology of Female Gonads................. 47

SUMMARY....................................... 51

IITERATURE CITED. . . . . . . . . . . . . . . . . . . . . . 53

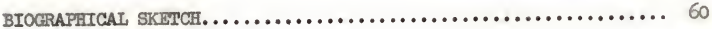




\section{LIST OF TABLES}

Table

1. The length, width, and proportional size of the oolcyte of primary follicles of the eye gnat.................. 23

2. The frequency of copulation of male eye gnats............ 29

3. The length and with of the testes of eye gnats at different sex ratios................................... 31

4. Oviposition of mated and unmated female eye gnats........ 34

5. Preoviposition period of mated and unmated female eye gnats. 35

6. The per cent mortality and fertility of eye gnats exposed to residual deposits of tepa on glass for 4 hours then held for 10 days................................ 37

7. The per cent mortality and fertility of eye gnats when exposed to boney contalning tepa for 3 deys then held for 10 days.

8. The per cent mortality and fertility of eye gnats when exposed for 3 days to a sugar solution treated with tepe, metepa, and apholate, then held for 10 days on honey....... 39

9. The per cent fertillty of eye gnats when sexes were treeted separately or simaltaneously with tepa, metepa, and apholate In the food (sugar solution) for 3 days, then held for 10 days........................................... 42

10. The effect of tepa, metepa, and apholate on the length and width of the testes of eye gnats, and on the proportionate length of the zone of transformation..................

11. The stage of development of the primary follicles in ovaries of eye gnats treated with tepa, metepa, and apholate in the food. 


\section{IIST OF ILIUSTRATIONS}

1. Mechanical asplrator used to manipulate eye gnats while anesthetized with carbon dioxide..................... 10

2. The internal reproductive system of the male eye gnat. $100 \mathrm{X} 13$

3. Cross-section of eye gnat testis. $226 x . . . \ldots \ldots \ldots \ldots \ldots \ldots .15$

4. Mature sperm cells from eye gnat test1s................ 16

5. The intermal reproductive system of the female eye gnat.

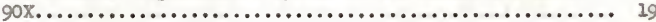

6. Hive stages in the follicular development of the egg of the eye gnat................................. 2l-22

7. Distal end of eye gnat accessory gland shown in close assoclation with lateral edge of ovary................ 27

8. Plot of the length of the zone of transformation expressed. as the per cent of the length of the testes of eye gnats... 32

9. Testes from chemosterilized male and untreated male eye

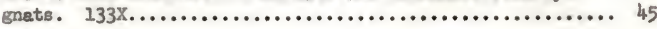

10. Sagittal section of testes from chemosterilized male (260x) and untreated male $(360 \mathrm{x})$ eye gnats.................. 46

11. Ovaries from chemosterlilzed female and untreated female eye

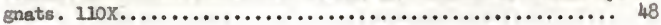




\section{INTPODUCPION}

Although a large number of papers on the biology and ecology of Hippelates species are avallable little information has been accumlated on reproduction in this group of insects. Similarly, a great deal of work has been done with insecticides for the control of Hippelates but the value of insecticidal applications for the reduction of Hippelates populations is questionable. Control of Hippelates is vital in some heavily infested areas because of their pestiferous habits (Schwarz, 1895) and medical (Bengston, 1933) and veterinary (Sanders, 1940) importance. Although Hippelates have never been shown to be vectors of any disease, they are mechanical carriers of the causal agent of yaws (Kunm and Turner, 1936) and other Infectious diseases. With the advent of sterilization techniques and the successful eradication of the screw-worm Ily from Florida (Beumbover et al., 1959), a new approach to insect control and/or eradication seemed feasible. The success of the screw-worm program suggested the possible use of chemicals in adaptations or extensions of the sterility approach to Hippelates control. The Induction of sterility in insects by exposure to several chemicals had already been demonstrated but little interest was generated in the practical usefulness of such compounds until the screw-worm program demonstrated the effectiveness of sterile males in reducing the reproductive potential of natural populations. Knipling discussed the possibilities of insect control through the use of aterile 
males in 1955 and later, in 1959, he suggested the theoretical advantages of the use of chemicals to induce sterility in a large segment of the natural population. A year later, LaBrecque et al., demonstrated that several compounds induced sterility in house flies, Musca domestica Linnaeus. In 1961, IaBrecque showed that sterility of a type similar to that caused by radiation was induced in both sexes of house flies by aphamide, tepa, and apholate and he deslgnated the compounds as chemosterilants.

The work of this dissertation was initiated in February, 1961, with the hope of showing the histological damage induced by chemosterilants on the reproductive system of Hippelates pusio Loew. At the start of this project no Investigation of this type had been conducted on any Insect nor had the reproductive system of any Hippelates specles ever been described.

The major aims of this study were: (1) to anatomically define the male and female intemal reproductive systems, (2) to chemically sterilize both sexes, (3) to determine the histopathological effects of the chemosterilants on the reproductive system, and (4) to make observations on the reproductive behavior of both sexes. It was hoped that these findings would provide a basis for further study and evaluation of chemosterllants against $\mathrm{H}$. pusio leading to an ultimate program for the control or eradication of the species.

During this course of study many new and interesting observations were made in the various aspects of the work. Some of these findings have created new problems and questions which undoubtedly are a field for study in themselves. A further anelysis of some of the various aspects of reproduction and chemical sterilization could lead to fruttful results. 
REVIEW OF IITHRATURE

Organs of Reproduction in Insects

A generalized description of the male reproductive organs is given by Snodgrass (1935). He stated that the internal organs of reproduction in male insects consist of a pair of testes, a pair of lateral ducts and an efaculatory duct. Frequently accessory glands are present which may be in the form of pouches or blind tubes branching from the upper end of the ejaculatory duct. In Diptera, the single sac-like testis has many shapes and forms depending on the species studied. In Drosopnila the testis may be ovold, curved, conical or spiral (Stern, 1941). It is pear-shaped in Musca (West, 1951) and a tubular gland in Glossing (Buxton, 1955). According to Wigglesworth (1953) the testis of insects is divided Into four main zones: (1) zone of spermatogonia (undifferentiated sperm cells), (2) zone of spermatocytes (dividing spermatogonia inside spermacysts), (3) zone of maturation and reduction (pre-spermatids and spermatids), and (4) zone of transformation (immature and mature sperm cells with a partially or Pully differentiated tail). In adult Drosophila, Clayton (1957) noted that during the 13 days of adult life the average number of spermatogonia decreased only slightly but the zone of transformation gradually increased in size. However, in some insects (Blatta, Wassilleff, 1907; and Bombyx, Omura, 1936) spermatogenesis does not occur In the adult stage and the testes atrophy. 
The testes connect at their base to vasa deferentia which are usually simple tubes with a thick cellular epithelium limited by a basement membrane and a strong nuscular coat of circular fibers (Snodgrass, 1935). The vasa deferentla are direct derivatives of the posterior unspeclalized parts of the genital ridge whlch are continuous with the ventral strands of the gonads. They connect to an ejaculatory duct which is formed as a median ventral invagination of the ectoderm at the posterior end of the ninth abdominal segment. The epithelium of the efaculatory duct is surrounded by a strong muscular sheath usually consisting of circular and sometimes longitudinal pibers (Snodgrass, 1935). The male accessory glands generally arise from the anterior end of the ejaculatory duct. They usually function as secretory glands with a mucous or viscid discharge.

The internal organs of reproduction in female insects are in many respects similar to those of the male. The essential parts of the female reproductive system are: (I) a palr of ovaries, (2) two lateral oviducts converging posteriorly from the ovaries, and (3) a median oviduct recelving the lateral ducts anteriorly and opening posterlorly to the exterior at the gonophore (Snodgrass, 1935).

In most insects the ovary consists of a group of cylindrical or tapering units, the ovarioles. Wigglesworth (1953) described four zones of the ovariole: (1) the terminal fllament, which serves to attach the ovary to the body wall, (2) tbe germarlum, which consists of primordial germ cells which differentiate into odcytes and nutritive or nurse cells), (3) the vitellarium, a series of obcytes, each enclosed in an epithelial sac or follicle, which become progressively larger towerd the lower end, and (4) an ovarlole stalk, a thin-walled tube leading to the 
oviduct. The ovariole may be of several types depending on the means by which the odcyte is nourished. The polytrophic type of ovarioles each have an obcyte and a number of nurse cells enclosed with it in its follicle (Wigglesworth, 1953).

Christophers (1911) described five stages of the development of the primary follicle of the mosquito ovariole: (1) no obleyte formation, (2) obcyte occupying up to one-half of the follicle, (3) obcyte occupyIng up to three-fourtias of the first follicle and the second follicle in stage one, (4) follicle taking the shape of a mature mosquito egg, and (5) fully developed egg with the second follicle in stage two.

When the mature egg is released from the ovary it reaches the outside via the oviduct. The two lateral oviducts are very short in Musca and unite almost at once to form the median or conmon oviduct (West, 1951). The common oviduct of Aedes widens into a short muscular vagins and is attached to the body wall of the elghth abdominal segment by somatic muscles (Curtin and Jones, 1961). The vagina of insects is a direct derivative of the genital chamber and not a continuation of the oviduct. The point of union between the true oviduct and the vagina is marked approximately by the opening of the spermatheca into the anterior end of the vagina.

The spermathecae in most insects are sac-like receptacles for the storase of spermatozoa after insemination. There may be from one to several spermsthecae depending on the species studied. There is usually a spermathecal duct and a gland associated with the spermatheca. The spermatheca is primarily an Invagination of the body wall at the posterior end of the elghth abdominal segment and it lies in the dorsal wall of the vagina if the genital chamber has the form of a vaginal tube (Snodgrass, 1935). 
Posterior to the location of the spermatheca on the vagina are the accessory glands which are thought to secrete a cement for attaching the eggs to a support or a material for covering the egg (Snodgrass, 1935). In insects having a vaginal pouch, the accessory glands open either at the end of the vagina or in 1ts dorsal wall.

\section{Chemosterilization of Insects}

An insect's ability to reproduce mey be totally or partially destroyed by chemical treatments. Two types of chemicals known to have this effect are antimetabolites and alkylating agents. The antimetabolites, according to Woolley (1952), are compounds essential to cell development which have been altered slightly and ellcit signs associated with a specific lack of the metabolite which they resemble when introduced into an animal. The mode of action of antimetabolites has been recently discussed in Timmis (1961) and the reader is referred to this paper and Woolley's (1952) text for more detalled accounts. Antimetabolites such as the well-known folfc acld antagonists have been found to induce sterility only in female insects (see Goldsmith and Frank, 1952; LaBrecque et a.., 1960; and Mitlin et al., 1957) and are not considered potentially useful for insect control as chemosterilants.

The alkylating agents replace hydrogen with an alkyl group in fundamental genetic material with an effect similar to that of irradiation and are called radiomimetic compounds (Alexander, 1960), but the mode of action is not well understood. Information on this subject may be found In the papers of Blesele (1958), Borkovec (1962) and Stacey et al. (1958). The chemical nature of alkylating agents in general is discussed by Ross (1962) and those which show greatest promise as insect chemoster1lants (aziridine derivatives) are discussed by Borkovec and Woods (1963). 
Of the 41 chemicals which have shown promise as insect chemosterilants, 14 are axiridine derivatives, including tepa, metepa, and apholate (Smith et al., 1964). Some of the 1nsects which have been sterillzed with aziridines are:

Citrus red mite - aphamide, apholate, and tepa (Cressman, in press). Drosoph1la - apholate (Cantwell and Hennebberry, 1963).

Germen cockroaches - aphamide, apholate, methiotepa, and tepa (Burden and Smittle, 1963).

House Plies - apholate, meteps, and tepa (LoBrecque, 1961 and LaBrecque et al., 1963).

Mexican bean beetle - apholate (Henneberry et al., in press). 1962).

Mexican fruit Ply - aphamide and tepa (Shaw and Sanchez Riviello, 1961).

Mosquitoes - apholate (We1chas, 1962), and tepa (We1dhas et al.,

Screw-worm Ply - apholate (Chamberlain, 1962), metepa and tepa

(Gouck et al., 1963), methiotepa, thlotepa, and tretamine (Crystal, 1963). Stable Ply - apholate, metepa, and tepa (Harris, 1962).

Chemosterilants may act on the reproductive system of insects in three ways: (1) cause failure to produce ova or sperm, (2) cause death of sperm and ova after they have already been produced, and (3) produce multiple dominant lethal mutations, or infure the genetic material in sex cells. The third type of action is the most desirable because males sterilized in this manner compete readily with normal males for available females, and the transfer of motile syerm to the spermatheca of females satisfles the mating requirements as if the female had mated with a normal male (Smith et al., 1964).

Very little work has accumulated on the histological damage to 1nsect reproductive systems resulting from exposure to chemosterilants. The observations which have been made indicate that the chemicals cause sllghtly smaller gonads and chromosomal damage in treated insects as compared to untreated (Drosophila, Cantwell and Henneberry, 1963; boll weevil, Ifindquist et al., In ms.; house fly, Morgan and LaBrecque, 1962; and mosquito, Murrey, 1963). 


\section{MATERIALS AND METHODS}

The Orlando strain of $\mathrm{E}$. pusio was used in all tests. The Bnats were sexed whlle anesthetized with carbon dioxide. The transfer of gnats to test cages and the separation of the sexes was performed with a mechanical asplrator developed specifically for this purpose. The mechanical aspirator consisted of four principal parts (PIg. 1); a base (3) which contained the vacuum source and accessories, an anesthetization chamber (4), a collection chamber mounted on a wooden support (1), and a suction gun (2). In operation a collection cage was snapped into place and the insects were placed on the screen of the anesthet1zation chamber which was positioned under the low objective of a stereoscoplc microscope. The gnats were plcked up with the suction gun. The vacuum produced by the power source vas just enough to plck up the gnats and hold them in the distal 1 inch of the pipette. Transfer from the suction gun was accomplished by attaching a tube from the second carbon dioxide valve to the tip of the glass plpette and blowing the insects into the collection chamber.

The holding cages used in the tests were of two types. One type, used for holding 25 or more pairs of gnats, consisted of a plastic refrigerator carton with the top modified to accomodate two $1 / 2-1$ nch cloth-covered alr holes and a center bole containing a cotton roll of the type used by dentists. The second type of cage was a 10-dram Glass shell vlal with a snap cap, used to contain 10 gnats or less. The 
EXPLANATION OF FIGURE 1

1- Support Arm

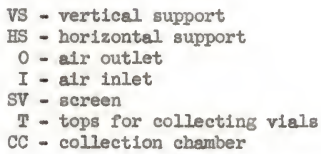

2- Suction Gun

SW - 3-position switch

$I$ - air inlet

V - 10-dram plastic vial

PT - 3/8 in. plastic hose shim

$F$ - funnel

SC - snap cap

G - glass pipette

1-3 - wires to power supply

3- Base

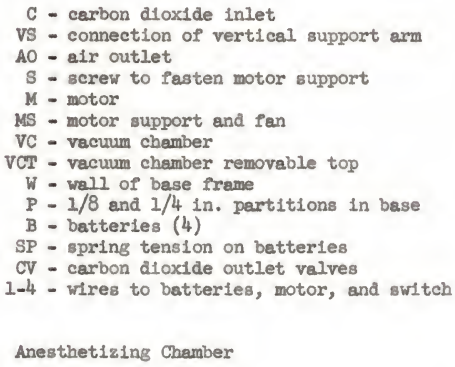




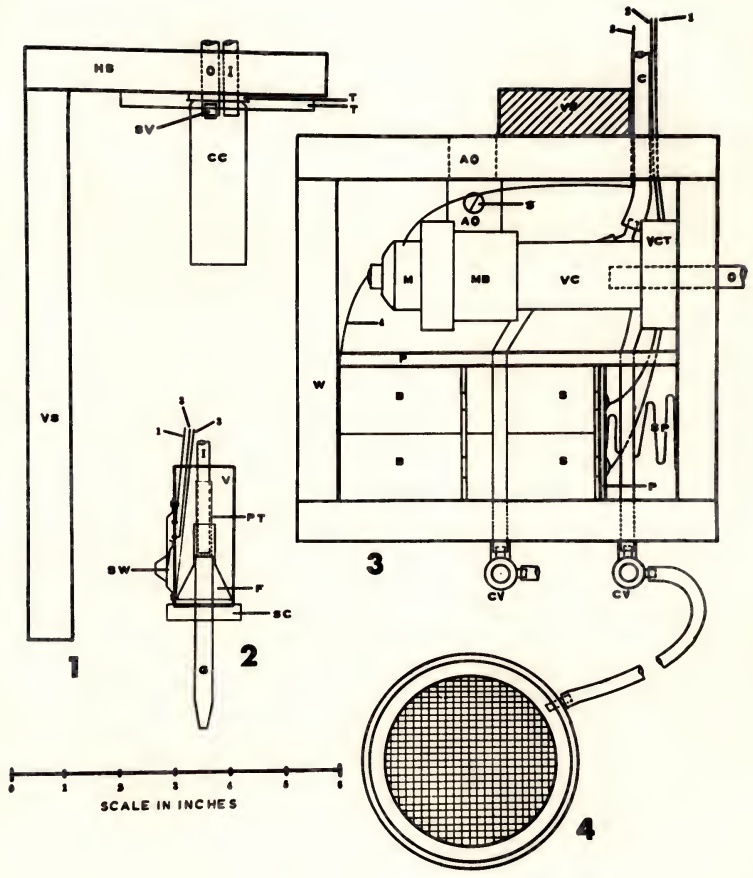

Figure 1.--Mechanical aspirator used to manipulate eye gnats while anesthetized with carbon dioxide. 
plastic top was modifled so that it contained a hole 1-Inch in diameter which was Pltted with a $30 \times 30$ mesh plastic screen. A $35 \mathrm{~mm}$. $\times 1 \mathrm{~mm}$. capillary tube containing honey was inserted part-way through the screen. The breeding colony was maintained according to the method of Jay (1961).

All dissecting was done in B.B. saline (Bphrussi and Beadle, 1936). Observations on the reproductive system were made using a Spencer-Phase microscope in phase-contrast.

The chemical sterilants were obtained from the USDA and kept in concentrated form at $-20^{\circ} \mathrm{C}$ unt1l used. For the feeding tests, dilutions of the chemicals were made in solutions of sugar or honey in delonized water. For the residue tests, all dilutions were made in absolute methanol or absolute ethanol. At least 25 pairs of gnats, collected less than 36 hours after adult emergence, were exposed to each concentration tested. In the feeding tests a 3-day exposure period was used after whlch the gnats were held for 10 additional days. In the residue tests, 10-dram vials were treated with $1 / 2 \mathrm{ml}$. of the solution per vial. After the vials were treated they were allowed to ary overnight. Gnats were exposed to the resldue for 4 houxs. After the exposure the gnats were transferred to l-pint containers, supplied with honey, and held for 10 days.

In both food and resldue tests, gnats were allowed access to food prior to exposure. Mortallty counts were made after the exposure period and after the 10-day holding perlod. Sterillty was assayed by placing the eggs from each cage in water, holding 3 days and then determining the batching rate by observation in a black, gridded petri dish. If more than 150 eggs were obtalned from a cage, a 50-egg sample was separated 
from the rest of the lot and used to determine the hatching rate. However, if the hatching rate in the sample was zero, the complete lot of eggs was examined and, if any had hatched, an estimate of the batching rate in the complete lot was used.

Abbott's (1925) correction formula was applied to both mortality and sterility if they exceeded 10 per cent in the untreated gnats. The corrected data were analyzed by probit analysis according to the method of Ittchifeld and Wilcoxon (1949). The standard errors, " $t$ " tests, " $F$ " tests, and Chl squares were calculated according to the methods of Snedecor (1961). Tests for significant differences between means were conducted according to the method of Duncan (1955). In the statistical tests a level of 5 per cent probability was used for signifleant differences. 


\section{RESUIMS AND DISCUSSION}

\section{Anatomy of the Internal Reproductive System}

Male

The male reproductive system of $\mathrm{H}$. pusio ( $1 \mathrm{fg} \cdot \mathrm{g}$ ) was found to consist of a pair of testes, a pair of short vasa deferentia, paired accessory glands, an unpaired efaculatory duct and the external genitalia.

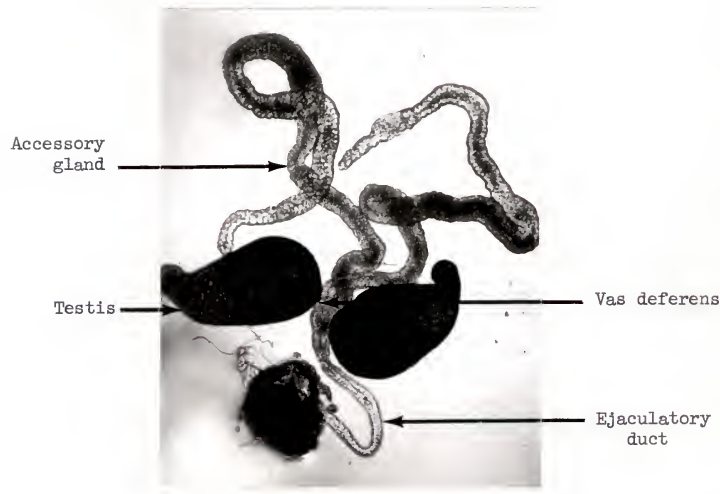

Figure 2.--The interial reproductive system of the male eye gnat. $100 x$. Testes.--The testes of $\mathrm{H}$. pusio lay dorso-laterally in the region of the third abdominal segment with their extremes extending into the second and fourth segments. The testis was well tracheated but no 
Innervation was observed with phase-contrast microscopy. The doublelayered testicular sheath contained orange-pigmented granules between the layers like that of Musca (West, 1951) and Drosophila (Stern, 1941 ). Sterm (1941) believed the pigmentation of Drosophile testes was secreted by the external testicular layer (tunica externa). The testicular sheath of mosquitoes is neither pignented nor doublelayered (Hodapp and Jones, 1961).

The testes of $\mathrm{H}_{\text {. pusio ( }}$ ig. 2) were single, sac-like organs as in most Diptera. They were pear-shaped in form, resembling those of mosquitoes (Hodapp and Jones, 1961). Internally they were not divided into distinct spermacysts such as those observed by Hodapp and Jones (1961) in the mosquito, nor was there an indication of spermacyst formation in the pupal testis, but a distinct regionalization of the testis did exlst. At the small knob-like apical end (germarium), spermatogonia were predominant $(\mathrm{fig} \cdot 2)$. This zone was followed. posteriorly by the zones of spermatocytes, maturation and reduction, and transformation. The zone of transformation was the largest zone in the adult test1s. This area contained sperm bundles in which the long, wavy spermatozoa were grouped together with cytoplasmic connections (PIg. 3). The finding of sperm bundles in the testis is not an uncommon event. They have been observed in several insects such as Drosophila (Clayton, 1957), Chortophara (Payne, 1933), and Bombyx (Omura, 1938b). In $\mathrm{H}$. pusio the sperm bundles persisted as very coherent fascicle-like structures with nc trace of the individual spermatozos. remalning ( $\mathrm{fig}$. 4-b). These tube-like structures whipped about in E.B. saline but did not undulate like spermatozoa ( 1 lg. 4-a). The fascicles were observed to persist after transference to the female reproductive 


\section{5}

system. This is not in agreement with the findings of other workers in other species. Omura (1938a) noted that in Bombyx the sperm bundles rapidly separated into individual cells after deposition in the female. The exact role which the bundles of sperm in H. pusio females play in fertilization is not known; however, a freshly laid egg was found to have a sperm bundle attached to its micropyle. Their persistence in the female reproductive system is a curious phenomenon and their function is yet to be fully explained.

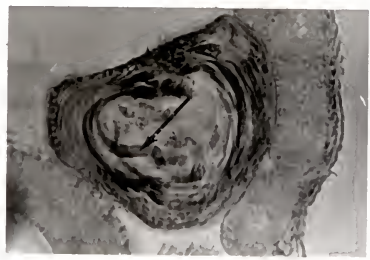

Fisure 3.--Cross-section of eye gnat test1s (arrow points to sperm bundle). 226x.

The spermatozoe in the testes frequently contained cytoplasmic droplets along the flagellum. The sperm were rod-shaped (P1g. 4-a) w1th no apparent head structure and appeared to be colled within the testes $(\mathrm{flG} \cdot 3)$. They remained motionless within the testis except when the contraction of the base of tre testis moved them about.

The testes in very young males were light orange in color. However, as the male aged the density of sperm increased in the posterior portion of the testis, giving it a dark brown to black color. 
The apical tip of the testis was sometimes in line vith the remainder of the testis and sometimes recurved, occasionally even doubling back to touch the main body of the testis. Usually the recurvature did not exceed $90^{\circ}$.

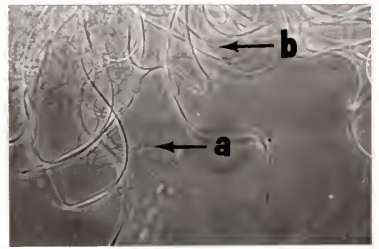

Flgure 4.--Mature sperm cells from eye gnat testis. (a) spermatozoa, (b) sperm bundle.

Vas deferens.--The vas deferens ( $f 1 g .2)$ was connected to the base of the test1s on its inner surface. It was very short as in Musca (West, 1951). The wall of the vas deferens was whit1sh and somewhat translucent as seen with phase microscopy. The cells of the wall contained very small spherical nuclel. The vasa deferentia appeared to serve only as a means of communication between the testis and ejaculatory duct. In other insects the vasa deferentia may also serve as a sperm storage organ through a modification in the form of a seminal vesicle such as that found in mosquitoes (Hodapp and Jones, 1961) and the corn ear worm (Callahan and Casc10, 1963).

The vas deferens of $\mathrm{H}$. pusio was contractile, as in Drosophila (Nonidez, 1920) and the corn eer worm (Callahan and Casc10, 1963). The vasa deferentia joined the ejaculatory duct on the same plane as the accessory glands. 
Accessory gland.--The paired innervated accessory glands (fig. 2) were contractile in E.B. saline. Their ducts contained large granules that were moved by peristaltic action toward the ejaculatory duct. The house fly has no accessory glands (West, 1951). However, in the mosquitoes that have been studied, the accessory glands are very prominent and are attached to the vasa deferentia by a thin filament.

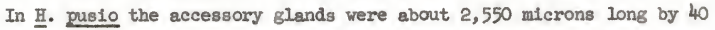
microns wide with little or no taper. They were two to three times as wide as the vas deferens. Large secretory cello were observed in their walls.

In some instances spermatozoa were found clustered in areas of the accessory gland, Increasing its diameter slightly. Areas Invaded by sperm appeared to contain a flner granular substance than areas without sperm. This is an uncommon Pinding in insects, although Ium (1961s) found a few sperm occasionally in the accessory glands of male mosquitoes and attributed this to the pressure of the coverslip. However, the preparations of $\underline{\text { H. pusio }}$ were not coverslipped and the condition occurred more frequently in older males than in young males, which suggests that the accessory gland may serve as a sperm storage organ. The vasa deferentia of $\underline{H}$. pusio probably could not serve as sperm reservolirs because of their extreme shortness. Therefore, the production of sperm by the testis may overload the ejaculatory duct and cause sperm migration or transfer into the accessory gland.

Ejaculatory duct.--The efaculatory duct (fig. 2) was very muscular and contained many spherical nuclei in its walls. It was bulb-shaped at the anterior end and tapered into a narrow tube. The efaculatory duct of $\mathrm{H}$. pusio did not follow an irregular course to the 
penis as in the house $11 \mathrm{y}$ (West, 1951), nor did it enlarge into an ejaculatory sac as in Drosophila (Nonidez, 1920) and the house Ily. It more nearly resembled the ejaculatory duct of Culicine mosquitoes (Hodapp and Jones, 1961) in general shape.

In Drosophile the efaculatory sac acts as a pump to arive the sperm through the lumen of the duct. In H. pusio the bulbar portion of the ejaculatory duct may possibly act as a pump which forcibly ejects the spermatozos from the lumen of the duct. However, the exact mechanism of sperm transfer in $\mathrm{H}$. pusio remains uniknowm.

Within the Iumen of the ejaculatory duct of $\mathrm{B}$. pusio there were granules, possibly from the accessory glands, after the third day of adult Iffe. The density of the spermatozos in the lumen appeared to increase as the male aged. Inm (1961b) considered the fluid from the male mosquito accessory gland to act only as a medium for the spermatozoa during ejaculation and ald not regard the Glandular secretion as having a stimulatory effect on the spermatozos as in the case of Bombyx (Omara, 1938b).

\section{Female}

The female reproductive system, occupying the posteriormost portion of the abdomen of $\mathrm{E}$. pusio was found to consist of two overies, an efferent duct system, two sperm-storing organs, two accessory glands, and the external genitalla (fig. 5.) The ovaries were joined by two very short lateral oviducts to a common median oviduct. The median oviduct entered the tube-like genital chamber or vagins. The vagina opened to the exterior on the eighth abdominal segment. A bursa (located ventrally), a pair of spermathecae and a pair of accessory glands (located dorsally) opened into the vagina. 


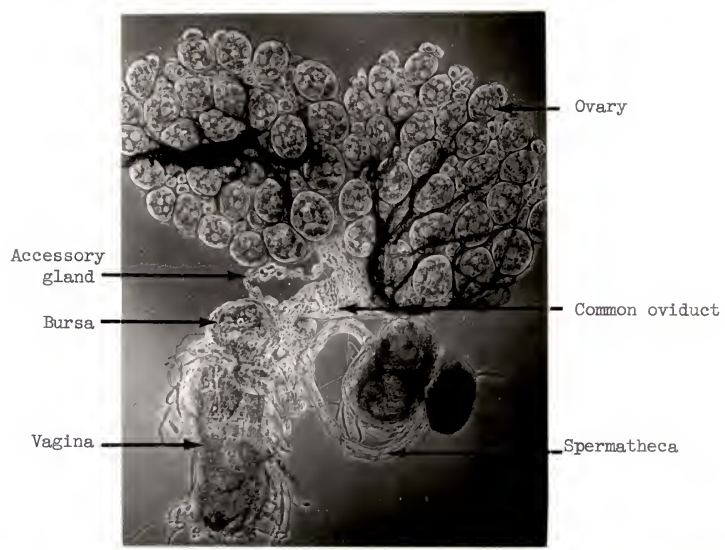

Flgure 5.--The internal reproductive system of the female eye gnat. 90x. Ovary. - The inmature ovary resembled a bunch of grapes in shape, was well tracheated and contracted slightly in E.B. saline. As observed by Kunm (1935) for $\mathrm{H}$. pallipes the ovarles were whitish and varied greatly in size according to the stage of development. The mature ovaries were ovate-shaped and occupied the greater portion of the abdomen, distending it by their growth. Their distal ends were unattached, with no terminal I1gament such as that in Drosophila (Miller, 1950). The ovaries were supported in the abdomen by the numerous tracheal branches with which they were supplied. The ovarian sheath was very thin and appeared like a web of loose crossatriations over the ovartoles. 
Bach ovary consisted of a group of parallel egg tubes or ovarioles. The total number of ovarioles found in both ovaries of H. pusio averaged $40.2 \div 5.7$, as compared to 70 in the house rly (West, 1951) and 20 to 40 in Drosoph1la (Miller, 1950). The ovarioles were directed toward the internal calyx at an oblique angle and held together by the ovarian sheath. Bach ovariole consisted of a terminal filament at the distal end, followed by the germarium, a tapered monillform series of two to four follicles ( $1 \mathrm{gg} .6$ ) and, at the basal end, a pedicel.

The terminal filament was short and attached to the germarium, which was oblong in shape and showed a granular cell structure (f1g. 6). The germarlum was not compartmented as in Drosophila (Miller, 1950) but more closely resembled the undifferentiated nucleated tissue of the mosquito germarlum (Bertram, 1959). The basal portion of the germarium became enlarged as a follicle was belng developed and at the completion of follicular development wes separated from the distal portion by a short stalk. Bach follicle became 1ncreasingly larger toward the basal portion of the ovariole. The basal-most follicle was the primary follicle which differentlated into a mature egg.

Primary follicular development was divided into five stages (after Christophers, 1911). In the flrst stage, the spherical primary follicle was the larger of the two pollicles present (fig. 6-a) and contained granular cytoplasm with no odcyte differentiation. In th1s stage the primary follicle was about 79 microns ln length by 72 microns In width (table 1) and nurse cells becune clearly defined as development progressed. The wall of the primary follicle was much thicker than thet of the other follicle and the germarlum. 
21

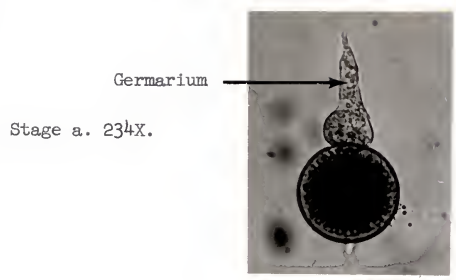

Stage b. $215 \mathrm{X}$.

Secondary follicle

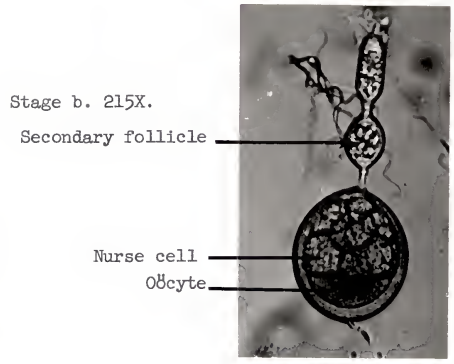

Stage c. $270 x$.

Nurse cell obcyte
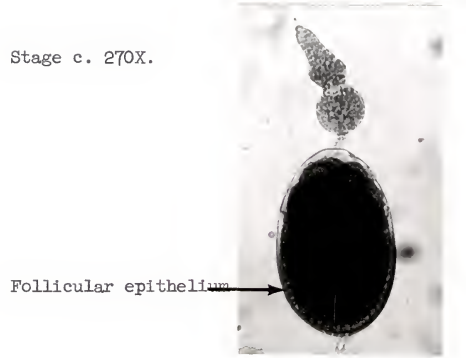

Figure 6.-mive stages in the foll1cular development of the egg of the eye gnat. 


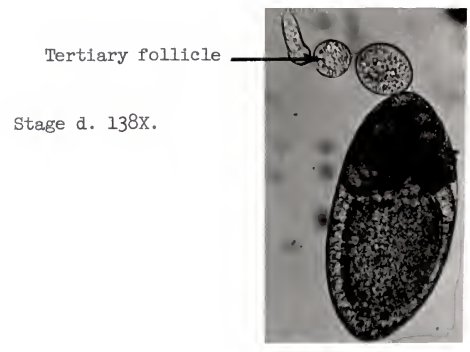

Stage e. 129x.

\section{Micropyle}

Figure 6.--Five stages in the follicular development of the egg of the eye gnat. 
Table 1.--The length, width, and proportional size of the obcyte of primary follicles of the eye gnat.

\begin{tabular}{|c|c|c|c|c|c|c|}
\hline $\begin{array}{l}\text { Follicle } \\
\text { stage }\end{array}$ & $\begin{array}{l}\text { Nhumber } \\
\text { measured }\end{array}$ & $\begin{array}{l}\text { Iength } \\
\text { Average }\end{array}$ & $\begin{array}{l}(\mu) \\
\text { SE }\end{array}$ & $\begin{array}{l}\text { Width } \\
\text { Average }\end{array}$ & $\mathrm{SE}$ & $\begin{array}{c}\text { \% of length } \\
\text { occupied by obcyte }\end{array}$ \\
\hline $\begin{array}{l}1 \\
2 \\
2 \\
3\end{array}$ (late) & $\begin{array}{l}6 \\
5 \\
4 \\
7\end{array}$ & $\begin{array}{r}79 \\
102 \\
104 \\
272\end{array}$ & $\begin{array}{l}0.94 \\
1.5 \\
0.81 \\
5.9\end{array}$ & $\begin{array}{r}72 \\
79 \\
91 \\
151\end{array}$ & $\begin{array}{l}1.9 \\
1.2 \\
1.2 \\
0.75\end{array}$ & $\begin{array}{r}0.0 \\
25.9 \\
36.4 \\
72.6\end{array}$ \\
\hline
\end{tabular}

In the second stage of development (f1g. 6-b) obcyte formation had begun and yolk granules were deposited. In this stage the obcyte occupied up to $1 / 2$ the length of the follicle. The follicle increased 10 to 25 per cent in size (table 1). The wall of the follicle became increasingly thicker, with the follicular epithelium constituting the greater portion. The nurse cells had approximately doubled in size by the end of this stage. The second follicle of the ovarlole was in stage one and the germarium had not yet begun to develop a third follicle.

Ey the third stage ( $1 \mathrm{gg} .6-\mathrm{c}$ ), the primary follicle had become more ovate and was about 272 microns in length by 151 microns in vidth (table 1). The obcyte occupied approximately one-half to three-fourths of the follicle. During this stage the nurse cells were quite large and the follicular epithellum aid not sursound them as in the earlier steges. The follicular epithellum contained two to three rows of columnar cells with large oval nuclel. The germarium had begun to differentiate a third follicle.

In the primary follfcle the nurse cells had begun degeneration during stage four (f1g. 6-d) and subsequently formed a polar cap 
around the anterlor of the obcyte at the future location of the micropyle. The follicular eplthelfum surrounding the obcyte had begun degeneration also. The third follicle was completed in this stage and the beginning of a fourth follicle appeared as a slight englargement of the germarium. Both the second and third follicle were st111 in stage "a".

In stage five (fig. 6-e) the obcyte occupled the whole primary follicle, the chorion pattern was easily discernible, and the micropyle was apparent. The follicular wall degenerated unt1l it resembled a thin tunica and was closely associated with the ovarian sheath. The second and third follicles had remained unchenged and the basal. enlargement in the germarium had undergone very little additional differentiation. It took approximately 72 hours to complete follicular development at about $24^{\circ} \mathrm{C}$. This was about the same rate of development King et al. (1956) observed for Drosophlla follicles. Oviducts and vagina.--The lateral oviducts were short tubes without an expansion such ss that observed in Drosophila (Miller, 1950). They united medially to form the common oviduct which was about 232 microns long and 78 microns wide when empty. The common oviduct entered the vagina dorsally between the openings of the ventral bursa and the dorsal spermathecae and accessory glands ( $\mathrm{flg} .5$ ).

The vagina was a highly muscular or gan about 600 microns in length and about 133 microns wide when empty. It was capable of considerable distention during egg deposition. The vagina was attached to the walls of the abdominal segment by somatic muscles. The anterioventral portion of the vagine was modified into a bursa. This organ 
1s homologous with the seminal receptacle of Drosophila (Miller, 1950) but bears little resemblance to $1 t$. In 프. pusio the bursa vas a nodule which protruded from the point of fusion of the vagina and common oviduct. It appeared to be a non-contractile sperm receptacle. When empty its cellular structure was much like that of the common oviducts and vagina but when full of spermatozos its cell structure appeared hyaline probably aue to the extension by the sperm. Spermatozos were present in this structure when the eggs were ready to be deposited and were subsequently transferred back to the spermathecae after egg deposition. The sperm were quite motile in the bursa and revolved within it at a great speed. Sperm alssected from 1 were of two types. The Mrst type was typical of spermatozoa in general, being long and containing numerous undulations along the flagellum. The second type was the fascicle-like structure discussed prevlously under the male. This type was unchanged from that which were found as a compact bundle of mature sperm located in the basal portion of the male testis. Freshly inseminated females contained seminal fluid in the vagina. It is not known whether the sperm were subsequently transferred first to the bursa or to the spermatheca.

The transfer of sperm from the spermatreca to the bursa when eggs are about to be laid is an unexplained phenomenon. It may be that the enlargement of the ripened ovaries causes a pressure on the spermathecae located between them, thus creating a stimulus which causes the migration of the spermatozoa. The forces which bring about this transfer are not known. The movement of sperm in female insects may be passive or active. The sperm are transferred to the spermathecae by movement 
of the reproductive system (Bphestia and Plodia (Norris, 1932; Rhodn1us, Davey, 1958; Aph1s queen, Snodgrass, 1956; and Zygaena, Hewer, 1934) or by their own movement (Bombyx, Omura, 1938a; Cimex, Abraham, 1934; and Drosophila, Nonidez, 1920).

Spermathecee and accessory glands.--Attached Immediately posterlor to the bursa and dorsal to 1 were the ducts of the two spermathecae (1ig. 5). The spermathecae were translucent tubes attenuated at the distal end and terminating in a gland. The besal portion of the tube was about 48 microns wide with a wall about 6.8 microns thick and was very lightly sclerotic. The spermathecae were quite constricted where they empty into the vagina. This region of the duct is very contractile and may afd in the transfer of sperm into and out of the duct. The attenuated portions of the ducts were narrow tubes that were colled like watch springs as in ㅍ. pallipes (Kumm, 1935). At the distal end of the attenuated portion, each duct was attached to a spherical gland, located at the center of the coll, which contained large secretory cells. The basic structure of the spermatheca of $\mathrm{H}$. Dusio was essent1ally similar to that of other insects but appeared to be a radical departure from the heavily sclerotized organ found in most Diptera, e.g. usually spherical in mosquitoes (Snodgrass, 1959), and house fly (West, 1952), but mushroom-shuped in Drosorh1le (Non1dez, 1920).

Within the spermathecal ducts of $\underline{\mathrm{H}}$. pusio, the sperm were not actively motile as in the bursa but undulations of the flagellae occurred. No spermatozos were observed in the gland attached to the end of the spermathecal duct.

Immediately posterlor to the attachment of the spermatheca on the vagina were a pair of contractile nodular filaments about 525 
microns long. The distal end of each was in a close association with the base of the ovary near 1ts lateral margin (I1g. 7). The duct of this organ was nebular and 1ts wall contained elliptic protruding nodules ( $11 g .5)$. The nodules were nebular like the duct but contained several dark zramules clustered in the center. In very young females the nodules were larger and more conspicuous than those of older females which have finished egg deposition. This organ appeared glandular but no secretory products were observed in 1ts duct. It 1s thought to be an accessory gland because of 1 ts position on the vagina, although 1ts true nature has not been revealed in this study. In other Insects, the female accessory gland hes been deslgnated by various names such as mucus gland (Christophers, 1923), cement gland (Howrard et al., 1913), and spermathecal gland (Detinovs, 1962) in the mosquito and colleterial gland or parovaria in Drosophila (Nonidez, 1920). In these instances the authors designated the gland according to the function they felt it performed; however, no such attempt was made in this study.

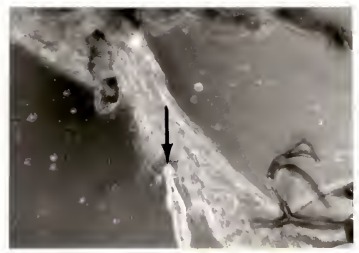

Migure 7.--Distal end of eye gnat accessory gland shown in close assoclation with lateral edge of ovary (arrow points to blind end of gland). 
Oviposition.--Gravid females were observed in the process of oviposition. First, the modifled portion of the abdomen or ovipositor (Hall, 1932) was extended to 1ts full length. Then an egg was released from the overy and passed into the common oviduct via the lateral oviduct. It paused in the common oviduct close to the bursa, which was PIlled with motile sperm, for 7 to 20 seconds. The egg was forced through the constriction of the common oviduct where it empties into the vagina by contraction of the former. It paused in the vagina for 20 to 25 seconds and constrictions of the vagina forced the egs out of the atrium located ventrally on the eighth abdominal segment. As the egg came through the atrium, the ninth and tenth segments lifted to about a $75^{\circ}$ angle and returned to their original position after the egg was released. The stimulus for egg deposition in $\underline{\text {. }}$. pusio is not known. In A. aegypt1, Curtin and Jones (1961) indicated that ovulation and oviposition are regulated by the nervous system.

\section{Reproductive Behavior}

\section{Age at Thme of Copulation}

Dissections of femsles confined with males of similar age showed no spermatozoa in the reproductive tract up to 36 hours after emergence, but sperm were found between the $36 \mathrm{th}$ and $48 \mathrm{th}$ hours after emergence. When newly emerged females were confined with males that were at least 3 days old, no spermatozoa were observed in the females until a period of 36 hours had elapsed. Ifkewise females confined with older males failed to produce hatchable eggs during the f1rst 36 hours after emergence. When males were less than 36 hours old they did not inseminate females which were more than 3 days old. 
These data were similar to those obtained by Murvosh et al. (In press) who showed that newly emerged house fly males and females did not mate for 16 and 24 hours respectively. In the mosquito, Wheeler and Jones (1960) showed that an actively mating male does not copulate freely with a newly emerged female partly because her terminalia are so greatly retracted and partly because she uses her metathoracic legs to prevent his clasping. In the case of the male mosquito, mating is prevented because of the unrotated terminalia (Hodapp, 1960). In males of ㅌ․ pusio, there is an anatomical indication of sexual immaturity in that there are very few or no sperm present in the efaculatory duct for 1 or 2 days after emergence. However, in females no such lack of sexual develogment is apporent during the first 36 hours of life, except for the apparent immaturity of the ovarles.

\section{Multiple Mating}

When a sexually mature male was offered five sexually mature females for a 24-hour period he inseminated as many as four (table 2). Table 2.--The frequency of copulation of male eye gnats.

\begin{tabular}{cccccccccccc}
\hline Male No. & 1 & 2 & 3 & 4 & 5 & 6 & 7 & 8 & 9 & 10 \\
\hline 1 & 0 & 4 & 2 & 2 & 0 & 3 & 1 & 0 & 0 & 1 \\
2 & 0 & 1 & 2 & 3 & 1 & 1 & 0 & 2 & 0 & 1 \\
3 & 2 & 2 & 1 & 1 & 1 & 0 & 0 & 0 & 0 & 0 \\
4 & 0 & 0 & 2 & 2 & 0 & 1 & 1 & - & - & - \\
5 & 0 & 2 & 3 & 3 & 1 & 1 & 1 & - & - & - \\
\hline
\end{tabular}

Individual males were capable of Inseminating from 6 to 14 females each over periods ranging up to 10 days. Copulation occurred most frequently from the second to the sixth day, at which time the males were 
5 to 9 days old. Whether or not a male copulates more than once with the same female could not be determined.

Aedes males were force-copulated by Jones (1961), who observed that they would copulate with about five females. However, he stated that copulation may occur without insemination. Virgin male Aedeg were found to inseminate about five Pemales in an hour when allowed to copulate freely. He found that the condition of sexusl depletion In males was maintained for about 24 hours after the males were removed from the semales.

Tests were conducted to determine whether or not multiple mating

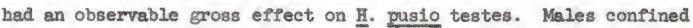
with females at a 1:10 ratio had slightly larger testes than those confined at a $1: 1$ ratio (table 3 ). This difference was signiflcant at the 5 per cent level. However, those males mated at a 1:1 ratio had significantly smaller testes than unmated males (table 3 ). It appeared that mating at a $1: 1$ ratio caused a slight decrease in testicular length over unmated males whereas mating at a 10:1 ratio appeared to increase the size of the testes. There was no apparent difference in the proportionate length of the zone of transformation between males at the varlous mating ratios. In Aedes, Schwartz (1961) found no difference between the slze of the testis of mated and unmated males but observed that sexual activity definitely hastens the full maturity of the spermatozoa. 
Table 3.--The length and width of the testes of eye gnats at different sex ratios.

\begin{tabular}{|c|c|c|c|c|c|}
\hline \multirow{3}{*}{$\begin{array}{c}\text { Sex rat1o } \\
\text { (male: female) }\end{array}$} & \multirow{3}{*}{$\begin{array}{c}\text { Number of } \\
\text { testes } \\
\text { meesured }\end{array}$} & \multicolumn{4}{|c|}{ S1ze of testes $(\mu)$} \\
\hline & & \multicolumn{2}{|c|}{ Length } & W1dth & \multirow[b]{2}{*}{$\overline{S E}$} \\
\hline & & Average & $\overline{S E}$ & Average & \\
\hline \multicolumn{6}{|c|}{0 to 12 day per1od (daily observations) } \\
\hline $1: 0$ & 86 & 466.7 & 5.2 & 187.4 & 1.8 \\
\hline $1: 1$ & 90 & 442.9 & 6.6 & 186.1 & 1.8 \\
\hline \multicolumn{6}{|c|}{10 to 24 day per1od ( 4 observations*) } \\
\hline $1: 1$ & 50 & 405.4 & 4.2 & 152.0 & 1.4 \\
\hline $1: 10$ & 50 & 434.2 & 4.4 & 161.2 & 1.8 \\
\hline
\end{tabular}

* Observations made on the 10th, 14th, 20th, and $24 \mathrm{th}$ days of adult life.

Test1eular Maturation

Measurements of the zone of transformation converted to a percentage of the length of the testis of $\mathrm{H}$. pusio Indicated the rate of spermatogenesis in the adult. This area increased in length at a decreasing rate with age $(\mathrm{Fg} .8)$. By the Plfth day one-half the length of the testis was occupied by the zone of transformation, an Increase of 40 per cent in the first five days of adult life. Beyond the Plfth day, the zone of transformation occupled approximately 70 per cent of the length of the testis as a maximum for 24 days of 11 fe. In rare instances with males greater than 12 days of age, the zone of transformstion occupled up to 100 per cent of the length of the testis. Clayton (1957) noted that the zone of transformation of Drosoph118 testes also increased in size during adult life.

Spermatogenesis appeared to be initiated in the pupal stage of H. pusio and apperently continued throughout the life of the male. This finding is in agreement with that observed for Drosophila 


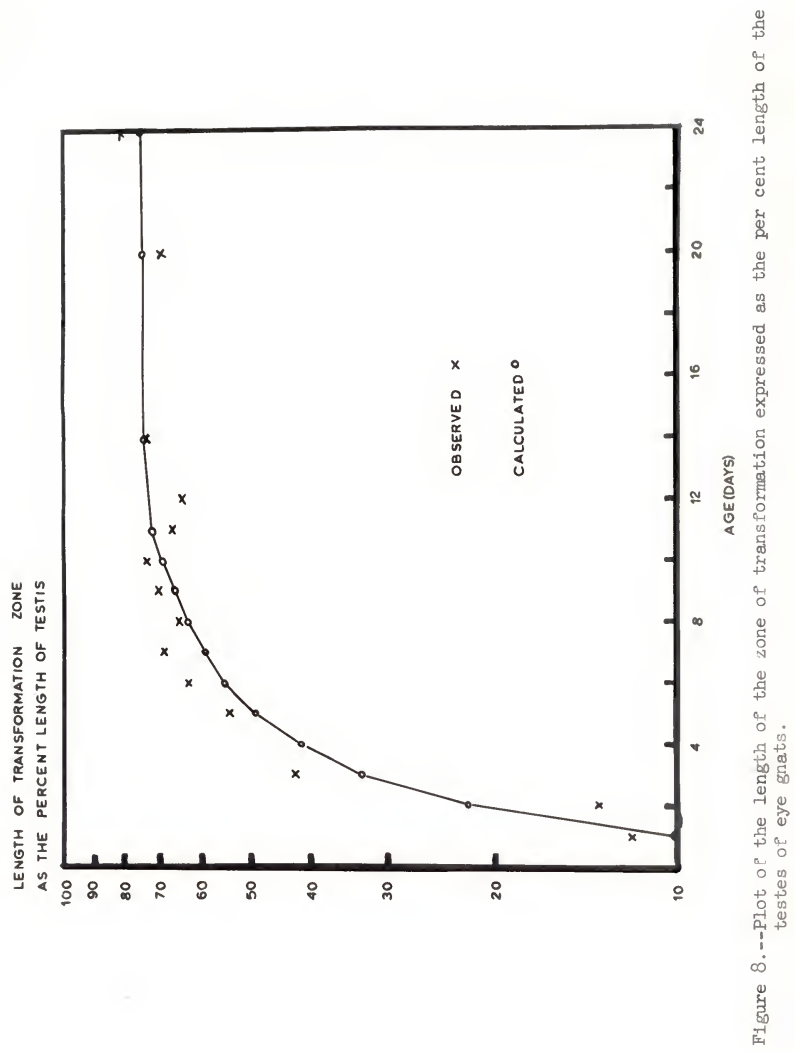


(Clayton, 1957), Blatta (Wassilleff, 1907), Pessalus (Krause, 1947), Bombyx (Omura, 1936), Carrponotus (Whelden and Haskins, 1953), Mycetophile (Abul-Nesr, 1950), and Ctenicere (Zacharuk, 1958). These workers also observed that spermatogenesis began in the prepupal or pupal stage.

The continuation of spermatogenesis in the adult of $\mathrm{H}$. pusio appeared to have a slight effect on the size of the testes. The average length of the testes was 436 microns with a range of 310 to 580 microns and the average width of the testes was 168 microns with a range of 120 to 280 microns. In a twelve-day study (table 3 ) there was a slight increase in the size of the testes as determined by an " $F$ " test. The testes sppeared to increase in length by about 60 microns by the fourth day. By the seventh day the testes decreased in length by about 60 microns but appeared to regain the 60 microns during the remainder of the twelve-day period. Correlating these observations with those on the rate of spermilogenesis it can be seen that the Increased size of the testis by the fourth day occurs at about the same time at which the test1s is making 1 ts greatest Increase in the zone of transformation (Pig. 8). After about the seventh day the length of the zone of transformation appeared to increase at a much slower rate (f1g. 8), and this would account for the gradual increase in the length of the testes. There is little indication from flgure 8 as to why the testis should decrease in size during the sixth and seventh day. However, the testis may not actually be growing during adult life but rather the testicular sheath 1s stretched to accomodate the Increased production of spermatozoa. As the sperm become tightly packed. within the testes by the sixth day it probably 
returns to normal size and again becomes gradually stretched as the sperm are produced throughout life. The 1ncreased size of the testis is about 13 per cent beyond that of a 1-day-old male. The above theory was tested to see if the testicular sheath was elastic enough to accomodate a 13 per cent Increase. Testes were placed in a hypotonic solution and the meximum distension was measured. It was found that the testicular sheath would stretch up to about 25 per cent of 1ts original dimension before breaking. Thus it seems posstble that the increased size of the testes of $\mathrm{H}$. pusio could be due to expension of 1 ts testicular sheath rather than to 1 ts growth. In some insects (Bombyx, Omura 1938b; Blatta, Wassilierf, 1907), spermatogenes1s does not continue in the adult stage and the testes atrophy.

A palred " $t$ " test indicated no significant difference between the pairs of testes of each male. However, in the mosquito Hodapp and Jones (1961) observed that one of the testes 1s usually smaller then the other.

Oriposition

A study was conducted to determine the number of eggs lald by mated and unmated females and to determine whether or not mating had an influence on the time of oviposition.

Table 4.--Oviposition of mated and unmeded female eye gnats*

\begin{tabular}{|c|c|c|c|c|c|c|c|c|c|c|}
\hline \multirow{2}{*}{$\begin{array}{c}\text { Number of } \\
\text { Pemales } \\
\end{array}$} & \multicolumn{10}{|c|}{ Number of females laying indicated number of eggs } \\
\hline & o & $2-5$ & $6-10$ & $11-15$ & $16-20$ & $21-25$ & $26-30$ & $31-35$ & $36-40$ & $41 \mathrm{up}$ \\
\hline & & & & & Mated & & & & & \\
\hline 50 & 15 & 5 & 0 & 1 & 1 & 9 & 4 & 5 & 4 & 6 \\
\hline 25 & 2 & 3 & 1 & 1 & 4 & 3 & 6 & 2 & 0 & 3 \\
\hline 25 & 5 & 2 & 1 & 2 & 0 & 3 & 3 & 3 & 3 & 3 \\
\hline & & & & & Unmated & & & & & \\
\hline 25 & 9 & 2 & 1 & 1 & 4 & 3 & 3 & 0 & 1 & 1 \\
\hline 25 & 10 & 2 & 0 & 0 & 2 & 2 & 7 & 1 & 1 & 0 \\
\hline
\end{tabular}

*18-day confinement period. 
Table 5.--Preoviposition period of mated and unmated female eye gnats."

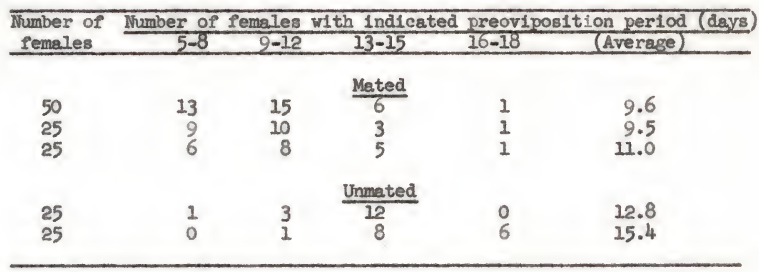

*18-day confinement period.

There was no significant difference between those females that oviposited in each test in the average number of eggs laid per female (25.8 eggs) as determined by an " $F$ " test (table 4). However, the preoviposition period was somewhat longer for unmated gnats than for mated gnats (table 5). In 5 to 8 days a maximum of 39 per cent of the mated females had begun to oriposit whereas a maximum of only 6 per cent of the unmated females had begun in the same perlod. By the 12th day, maximum oviposition had reached 83 per cent for mated females as compared to 25 per cent for unmated.

The over-all average of about 26 eggs per female is in general agreement with that of 24 eggs observed for Hilppelates by Hall (1932) and of 47.8 eggs by Mulla (1962) (10-day longer average oviposition period). The slight delay in oviposition by unmated females is in agreement with the results of Glaser (1923) for the house Ply and Curtin and Jones (1961) for the mosquito. 
Primary Follicular Development

Because of the difference in the length of the preoviposition period observed in the preceding section, a study was conducted to compare primary follicular development for 12 days in mated and unmated gnats. Actual follicular counts were made on those primary follicles which had initiated oblcyte development which corresponded to stages " $\mathrm{b}$ " through " $\mathrm{e}$ (

The data indicated no significant differences in the number of advanced primary follicles per day between mated and unmated gnats as determined by a paired " $t$ " test. The average number of advanced primary follteles per day per female was 23.5. This is in very close agreement with the average number of eggs laid per female in an 18day perlod, 25.8 .

It appeared quite evident in this study that slightly more than one-balf of the ovartoles per ovary had primary follicles in an advanced stage of development. There was no alternation of ovarian development since both overles appeared to contain an equal number of developing primary follieles. Advanced primary follicular development had not begun until the third day.

By ranking the mean number of advanced primary follicles per day per female and using Duncan's test for slgnificant differences it was found that no significant change occurred unt1l the tenth day. (See results below.)

$\begin{array}{lllllllllll}\text { Deys } & 3 & 4 & 6 & 5 & 7 & 8 & 9 & 12 & 10 & 11 \\ \begin{array}{l}\text { Ranked } \\ \text { mean }\end{array} & 27 & 27 & 27 & 22 & 22 & 18 & 16 * & 14 & 10\end{array}$

* Means for days three through nine are signteicantly different from days ten through twelve. 
The results of this test indicate the development of a second set of primary follicles by about the tenth day which was sienificently smaller than the first. The sum of these two ovipositions (28 and 16) correspond very closely with the average number of ovarioles per female $(40)$.

\section{Chemosterilization}

Preliminary Tests

Preliminary tests were conducted to determine an effective means for exposing both sexes of the eye gnat to chemosterilents. Residual deposits of apholate on glass were not effective at $10 \mathrm{mg} / \mathrm{sq}$. ft. This finding was in agreement with that obtained with house Plies (Meifert et al., 1963) and mosquitoes (We1dhaas and MoDupfie, 1963) exposed to residual deposits of $250 \mathrm{mg} / \mathrm{sq}$. Pt. However, tepa was effective at both 5 and $10 \mathrm{mg} / \mathrm{sq}$. ft. (table 6).

Table 6.--The per cent mortallty and fertility of eye gnats exposed to resicual deposits of teps on glass for 4 hours then beld for 10 deys.*

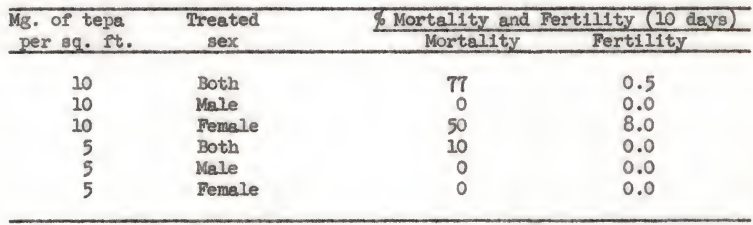

*Abbott's correction formula applied to mortality and fertility. (Two replicates, 25 to 30 pairs of gnats per test.)

Food tests indicated that tepa sterilized both sexes at concentrations of $1 / 2$ to 1 per cent when honey was used as a carrier. However, the results appeared somewhat inconsistent at different concentrations (table 7). 
Table 7.--The per cent mortallty and fertility of eye gnats when exposed to honey containing tepe for 3 days then held for 10 days.*

\begin{tabular}{|c|c|c|c|}
\hline $\begin{array}{l}\text { Concentration } \\
\text { of tepa } \\
\text { (\% wt/vol) }\end{array}$ & $\begin{array}{c}\text { Treated } \\
\text { sex }\end{array}$ & $\frac{2 \text { Mortality and }}{\text { Mortality }}$ & $\frac{\text { fertility after } 13 \text { days }}{\text { Fertility }}$ \\
\hline 1.0 & Both & 1.8 & 1.0 \\
\hline 1.0 & Male & 0.0 & 20.0 \\
\hline 1.0 & Female & 0.0 & 5.0 \\
\hline 0.5 & Both & 0.0 & 0.0 \\
\hline 0.5 & Male & 21.0 & 10.0 \\
\hline 0.5 & Female & 3.7 & 22.0 \\
\hline 0.1 & Both & 11.0 & 49.0 \\
\hline 0.1 & Male & 29.6 & 29.0 \\
\hline 0.1 & Female & 0.0 & 57.0 \\
\hline
\end{tabular}

*Abbott's correction formula applied to mortallty and fertility. (Two replicates, 25-30 pairs of gnats per test.)

Subsequently 1t was stated by Boricovec (1962) that the acidic nature of honey was capable of polymerizing the chemical. For this reason sugar solution was substituted for the honey. A 10 per cent concentration of a saturated solution was used. In subsequent tests sugar solution appeared to be an effective carrier and became the method of cholce for administering the chemicals to determine a sterilizing concentration and for observing the effect of the sterilant on the reproductive system.

Sterility and Toxicity

A study was conducted to determine the sterlilty and toxielty induced by tepa, metepa, and apholate when administered in the adult food for the first 3 days of 11fe. The average per eent mortallty and fertillty in three generations of treated gnats are presented in table 8 .

Sterility.--The data indicated that all the chemicals at the concentrations used ( 0.5 to 0.001 per cent) completely or substantially 
reduced the fertillty of surviving gnats. No eggs were deposited by gnats exposed to 0.5 per cent tepa and meteps. No egg hatch was obteined with tepa at concentrations of 0.1 to 0.01 per cent and fertility was less than 50 per cent at concentrations of 0.005 and 0.001 per cent (table 8 ).

Table 8. - The per cent mortality and fertility of eye gnats when exposed for 3 deys to a sugar solution treated with tepe, metepa, and apholate, then held for 10 days on honey.*

\begin{tabular}{ccc}
\hline $\begin{array}{c}\text { Sterilant } \begin{array}{c}\text { Mortality of } \\
\text { (\$) }\end{array} \\
\text { adult gnats } \\
\text { in } 13 \text { days }\end{array}$ & $\begin{array}{c}\text { of eggs } \\
\text { hatched }\end{array}$ \\
\hline 0.5 & $\frac{\text { Tepa }}{84}$ & 0 \\
.1 & 26 & 0 \\
.05 & 8 & 0 \\
.01 & 19 & 0 \\
.005 & 3 & 42 \\
.001 & 1 & 49 \\
& & \\
0.5 & Metepe & 0 \\
.1 & 99 & 1 \\
.05 & 20 & 14 \\
.01 & 3 & 36 \\
.005 & 3 & 33 \\
.001 & 1 & 49 \\
& 1 & \\
0.5 & & 0 \\
.1 & Apholate & 0 \\
.05 & 27 & 4 \\
.01 & 3 & 30 \\
.005 & 7 & 67 \\
.001 & 2 & 54 \\
& 15 & \\
\hline
\end{tabular}

*Abbott's correction formula was applied where mortality exceeded 5 per cent and fertility was less than 90 per cent in the untreated gnats. (25 palrs of gnats per concentration; 3 generations).

Netepa was less effective than tepe or apholate in reducing the fertility of gnats at concentrations of 0.5 to 0.01 per cent. Similar 
results with tepa and apholate were obtained with mosquitoes (Weidhaas et al., 1961; Weldheas, 1962) and with house flles (IaBrecque, 1961).

Toxic1ty.--Tepe and metepa at 0.5 per cent had a harmful effect, resulting in high mortality (84 and 99 per cent, regpectively). Mortallty at concentrations of 0.1 to 0.001 per cent of tepe and metepa ranged from 1 to 26 per cent. However, apholate at a concentration of 0.5 per cent produced only 27 per cent mortality. slope

The dats from table 8 were used to calculate the concentration to kill 50 per cent of the gnats with tepa and metepa (LC-50) and the concentration to obtain 90 per cent sterlilty (SC-90) for all three chemicals. The calculated SC-90, LC-50, and the slope of the regression line for each chemical are given below with the standard errors of each:

Chemical LC-50 SE Slope SE SC-90 SE Slope SE $\begin{array}{lllllllllll}\text { Tepe } & & 0.191 & .001 & 2.37 & .79 & .0077 & .0016 & 1.58 & .90\end{array}$ $\begin{array}{lllllllll}\text { Metepa } & .146 & .001 & 4.28 & .80 & .037 & .001 & 1.80 & .79\end{array}$

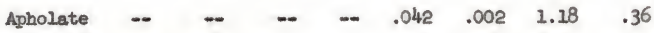

In computing the regression Iines for tepa, data from a test not shown in table 8 was used ( 3 per cent fertility at a concentration of 0.007 per cent).

The slopes of the sterility data were essentially the same and the $5 C-90$ 's of apholate and metepa vere simfler, but that of tepe was Pive to six times lower than both of the other sterilants.

The SC-90 of tepa obtained in this test agrees closely with the SC-90 of tepa for house Plies (Murvosh et 2l., 1964). The SC-90 of metepa and apholate obtalned by Murvosh et al. (1964) for house Plies 
1s about three times higher than that obtained in this study. However, this is not surprising since the wide variation obtained in the results of chemosterilant feeding studies indicates considerable differences In the response of an insect species to the chemical. This may be due to two causes: (1) there may be polymerization of the chemical causing differences attributable to the chemical itself and (2) there may be a deterrent effect of the chemical causing the insect to vary Its upteise of the food containing the chemical. This latter factor may account for the apparent reversal effect at the lower coneentrations whereby the 1nsect is not deterred to the same degree and acturilly takes up more chemicel. As suggested by Murvosh et al. (1964) less variable results might be obtained with a more precige method of administration. However, the feeding method serves to indicate whether or not the chemical will sterilize and the approximate concentrations at which sterility occurs.

The apparent wide range between toxicity and sterility for tepe obtained in this study indicated that tepa is capable of sterilizing at the lower concentrations without an apperent lethal effect such as that obtalned with metepa, where the ratio was quite low. A high ratio between toxicity and sterility is a desirable characteristic in a chemosterilant, in that the dosage does not become a critical factor. This is especially apparent with alkylating agents in which polymerization oceurs. The results of this study indicate the concentration of tepe can drop about 14-fold without causing a loss in the sterility effect. 
Effect of Chemosterllants on the Two Sexes

Preliminary tests with tepa (table 7) indicated that both sexes were sterilized when given treated food. A subsequent test was conducted with all three chemicals to determine whether or not males and females were both being sterllized. The results of this test indicated that a slightly higher concentration was needed to sterilize elther sex than $1 f$ both sexes were treated and mated. Males treated with tepa or metepa required lower concentrations than females to induce sterility (table 9).

Table 9.--The per cent fertility of eye gnats when sexes were treated separately or aivulteneously with tepa, metepa, and apholate in the food (sugar solution) for 3 days, then held for 10 days.*

\begin{tabular}{|c|c|c|c|c|c|c|}
\hline \multirow{2}{*}{$\begin{array}{l}\text { Treated } \\
\text { sex }\end{array}$} & \multicolumn{6}{|c|}{$\begin{array}{l}\text { T fertility at indicated \% concentration of the } \\
\text { chemosterilant }\end{array}$} \\
\hline & 0.07 & 0.05 & 0.03 & 0.01 & 0.009 & 0.007 \\
\hline \multicolumn{7}{|c|}{ Tepa } \\
\hline Both & $-\infty$ & 0 & 0 & 0 & 0 & 3 \\
\hline Male & -- & 0 & 0 & 0 & 0 & 25 \\
\hline Female & $-\infty$ & 0 & 1 & 45 & 50 & 50 \\
\hline \multicolumn{7}{|c|}{ Metepe } \\
\hline Both & 0 & 1 & 38 & 52 & 63 & $-\infty$ \\
\hline Nale & 0 & $3 \overline{8}$ & 100 & 100 & 100 & $-\infty$ \\
\hline Female & 100 & 88 & 100 & 100 & 100 & - \\
\hline \multicolumn{7}{|c|}{ Apholate } \\
\hline Both & $-\infty$ & 0 & 0 & 0 & 0 & 14 \\
\hline Male & - & 0 & 6 & 12 & 19 & 19 \\
\hline Femele & - & 0 & 0 & 5 & 12 & 50 \\
\hline
\end{tabular}

*Abbott's correction formula applied where fert1lity in untreated gnats was less than 90 per cent. (25 palrs of gnats per concentrat1on; 1 generation.) 
That the concentration to sterilize either sex is somewhat higher than that needed to sterilize both sexes appears consistent with the work reported by Lakrecque (1961) for house Plies.

Befects of Chemosterilants on the Reproductive System

Gnats were examined to determine the effect of the chemosterilants on the reproductive system between the 13 th and 14 th days after first exposure to the chemicals. The only hlstologlcal damage apparently caused by the chemicals occurred in the gonads and their gameteproducing cells.

\section{Histopathology of Male Gonads}

Tepe at concentrations of 0.1 and 0.05 per cent and apholate at 0.5 and 0.1 per cent reduced the length of the testes by almost 100 milcrons, or 23 per cent of the length of the testes in the untreated gnats (table 10 and $\mathrm{Plg} .9$ ). The length of the testes in gnats treated with 0.01 per cent of tepe or 0.05 per cent of apholate was approximately the same size as testes of untreated gnats. The highest concentrations of tepa ( 0.1 per cent) and apholate ( 0.5 per cent) also reduced the wlath of the testes by 17 to 23 per cent of the testes of untreated gnats (table 10). Metepa did not appear to have an effect on the length and widh of the testes (table 10). A similar effect was observed in Drosophila (Cantwell and Henneberry, 1963), in the boll weevil (Lindquist et al., in ms.), and in Culex (Murray, 1963).

All three chemicals at the higher concentrations caused abnormalities of the testes in some instances. The germarial region showed the greatest abnormalities. In some testes it wes slightly everted and in one testis it was quite distended. In several of the 
males one test1s appeared much smaller than the other. Another effect whlch was never observed in untreated gnats but occurred occaslonally In treated gnats was a wave-like effect over the periphery of the testes, giving then a shriveled appearance (PIg. 10).

Table 10.--The effect of tepa, metepa, and apholate on the length and width of the testes of eye gnats, and on the proportionate length of the zone of transformation.

\begin{tabular}{|c|c|c|c|c|c|c|c|}
\hline \multirow{3}{*}{$\begin{array}{l}\text { Concen- } \\
\text { tretion } \\
(\$)\end{array}$} & \multirow{3}{*}{$\begin{array}{c}\text { Number } \\
\text { of } \\
\text { observations }\end{array}$} & \multicolumn{4}{|c|}{ Size of testis $(\mu)$} & \multirow{2}{*}{\multicolumn{2}{|c|}{$\begin{array}{l}\text { Length of zone of } \\
\text { transformation as } \% \\
\text { of length of testis }\end{array}$}} \\
\hline & & \multicolumn{2}{|c|}{ Iensth } & \multicolumn{2}{|c|}{ Width } & & \\
\hline & & Avg. & SE* & Avg. & $\mathrm{SE*}$ & & \\
\hline \multicolumn{8}{|c|}{ Tepa } \\
\hline 0.1 & 28 & 349 & 19 & 134 & 7 & 89.2 & 5.7 \\
\hline .05 & 21 & 369 & 23 & 127 & 12 & 91.2 & 8.6 \\
\hline .01 & 16 & 465 & 20 & 146 & 12 & 64.9 & 8.0 \\
\hline \multicolumn{8}{|c|}{ Metepa } \\
\hline 0.1 & 19 & 412 & 23 & $\overline{152}$ & 11 & 54.2 & 18.5 \\
\hline .05 & 20 & 457 & 23 & 156 & 8 & 57.8 & 4.0 \\
\hline .01 & 27 & 447 & 20 & 155 & 8 & 69.4 & 5.0 \\
\hline \multicolumn{8}{|c|}{ Apholate } \\
\hline 0.5 & 32 & 377 & 21 & 126 & 6 & 97.2 & 2.3 \\
\hline .1 & 18 & 387 & 33 & 136 & 13 & 74.6 & 13.5 \\
\hline .05 & 15 & 486 & 27 & 151 & 9 & 80.4 & 10.4 \\
\hline \multicolumn{8}{|c|}{ Untreated } \\
\hline$-\infty$ & 54 & 447 & 12 & 164 & 12 & 61.6 & 3.4 \\
\hline
\end{tabular}

*SE is the standard error times the value for " $t$ " at the 5\% probabll1ty level.

The zone of transformation appeared to increase in length at the higher concentrations of tepa and apholate. In most instances with tepa at 0.1 and 0.05 per cent and apholate at 0.5 and 0.1 per cent, and infrequently at 0.05 per cent, the testes had no well-deflned separation of the zone of spermatogenesis as occurred in the testes of untreated gnats or those treated with metepe ( $1 \mathrm{~g} .10)$. When these testes were crushed at the germarlal region to free the cells within, 
only mature or nearly mature sperm were obtalned. Observations with phase contrast microscopy showed no spermatogonal cells or spermatids from testes which had no well-defined separations of the zone of spermatogenes1s (F1g. 10).

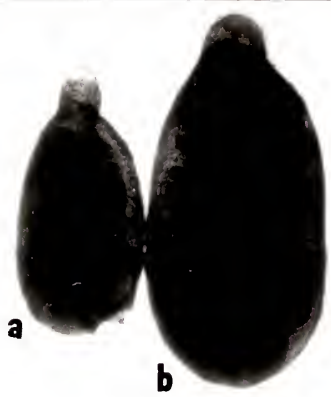

Figure 9.--Testes from (a) chemosterilized male and (b) untreated male eye gnats. 133x.

As shown in table 10, the increase in length of the zone of transformation expressed as a per cent of the length of the testis ranged from 13 to 35.6 per cent for apholate at all three concentrations, and from 27.6 to 29.6 per cent for tepa at 0.1 and 0.05 per cent. Netepa did not affect the length of the zone of transformation. In all the testes crushed and examined for sperm, the sperm were found to be motile and did not appear different from those of untreated gnat testes. Other organs of the male reproductive system showed no gross abnormal1ties. 

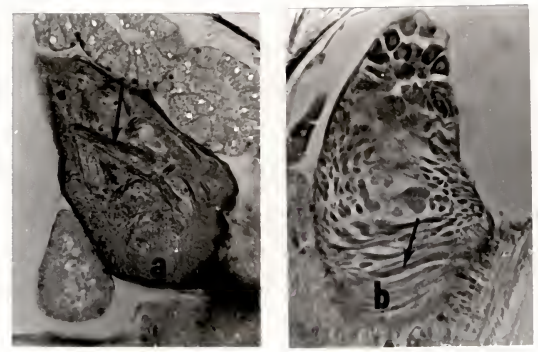

Figure 10.--Sagittal section of testes from (a) chemosterilized male $(260 \mathrm{x})$, and $(\mathrm{b})$ untreated male $(360 \mathrm{x})$ eye gnats (arrows point to sperm bundle).

The significant reduction in size of the testes after chemogterilization of the adult is an indication of two possibilities; (1) the testes were retarded in growth by the effects of the chemosterilant and/or (2) the testes atrophied due to the degenerative effects of the chemical. The latter assumption appears to be more reasonable since the study of untreated adult testes indicated no further growth of the testes during the flrst twelve days of life. When Insects are treated in the pupal stage a retardation of testicular development has definitely been shown to occur (Culex, Murray, 1963; and boll weevil, Iindquist et al., in ms.), and this may also bappen In the adult stage (Irosophila, Cantwell and Henneberry, 1963). The substantial reduction in size of the testes of treated $\underline{H}$. puslo observed in this study is probably correlated with the increase in the amount of mature sperm found in the treated testes over the untreated. testes. It seems highly probably that the germarlal region of the 


\section{7}

testis was irreversibly affected preventing further melotic and mitotic divisions ( $\mathrm{flg} .10)$. Those sperm cells which completed division subsequently elongated and differentiated into mature sperm whlle the other primary cells, grossly affected by the chemical, were possibly resorbed. This would result in a loss of cellular material within the testis and an expansion of the transformation zone throughout the length of the testis. The resulting sperm content would be somewhat Less than the original resulting in a partial collapse of the testicular envelopes thus producing a wave-1like effect over the periphery of the testis as was observed in this study (P1g. 10). Due to the loss of primoralal sperm cells, further increases in mumbers of sperm would not be possible; therefore, each time the male mated with a subsequent loss of sperm the testicular content would be slightly reduced. This factor also could be a contributing cause to the shrinkage of the testis.

Since the gnats were treated during the flrst three days of adult life, the maxinum size of the transformation zone would be about 40 per cent of the length of the teatis. However, the germarial zone occupies about 20 per cent of the length of the testis and if destroyed, the remainder of the sperm cells after completion of development courd occupy the whole test1s. That the 20 per cent collapse of the testicular envelope does not reault in a more severe effect on 1ts perimeter is probably due to the elastic1ty of the tunicas.

Histopathology of Female Gonads

of the 166 females observed, 131 had ovaries with the mejority of the primary follicles in stage " $\mathrm{a}$ ", 20 in stage "b", 3 in stage "c", 
and 12 in stage "d" or "e" (table 11). Tepa at 0.1 and 0.05 per cent and apholate at 0.5 per cent caused at least 90 per cent of the females to have abnormalities in the ovarioles, particularly in the area where the nurse-cells were undifferentiated from the obcytes. These cells were misshapen or degenerate and sometimes undistinguishable, in which case the area had a granular appearance (Pig. 11). Smaller primary follicles were observed in many treated females, which resulted in ovaries reduced in size as compared to those from untreated Pemales of the same stage (11g. 21). Primary follicles that had reached stage "b" and had more than 15 per cent oflcyte development did not appear to have degenerate or misshapen nurse cells. Those ovarles showing severe effects from the chemosterilant contalned degenerated and atrophled germarial areas (21g. 11). Similar effects occurred in house Plles as observed by Morgan and IaBrecque (1962).
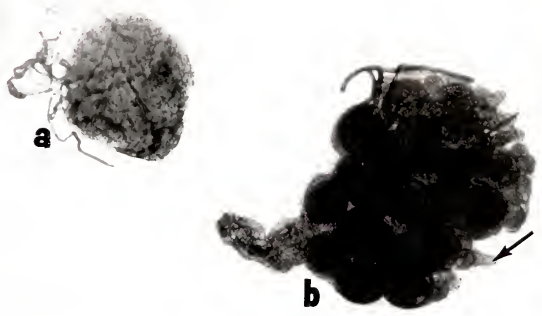

Mgure 11.--Ovaries from (a) chemosterilized fenale and (b) untreated female eye gnats. (Arrow polnts to germarium of ovarlole.) $110 x$. 
Table 21.- The stage of development of the primary follicles in ovarles of eye gnats treated with tepa, metepa, and apholate in the food.

\begin{tabular}{|c|c|c|c|c|}
\hline \multirow{2}{*}{$\begin{array}{l}\text { Concen- } \\
\text { tration } \\
\text { (\%) }\end{array}$} & \multicolumn{4}{|c|}{$\begin{array}{c}\text { Number of females with ovaries at indicated stage of } \\
\text { primary follicle development* }\end{array}$} \\
\hline & 2 & $\mathrm{~b}$ & c & $d$ and $e$ \\
\hline \multicolumn{5}{|c|}{ Teps } \\
\hline 0.1 & $16 * *$ & $=0$ & 0 & 2 \\
\hline .05 & $8 * *$ & 1 & 0 & 2 \\
\hline .01 & 11 & 2 & 1 & 1 \\
\hline \multicolumn{5}{|c|}{ Metepe } \\
\hline 0.1 & 11 & $\frac{\pi}{4}$ & 0 & 0 \\
\hline .05 & 9 & 2 & 0 & 0 \\
\hline .01 & 10 & 1 & 2 & 3 \\
\hline \multicolumn{5}{|c|}{ Apholate } \\
\hline 0.5 & $18 * *$ & 0 & 0 & 0 \\
\hline .1 & 9 & 0 & 0 & 2 \\
\hline .05 & 12 & 3 & 0 & 0 \\
\hline \multicolumn{5}{|c|}{ Untreated } \\
\hline- & 27 & 7 & 0 & 2 \\
\hline
\end{tabular}

* Stage a - obcyte undifferentlated from nurse cells; stage b odcyte occupying up to 50 per cent of the follicle; stage c - obcyte occupying more than 50 per cent of the follicle and nurse cells wlthout atrophy; stage d murse cells beginning to atrophy but chorion pattern not distinguishable; stage e - mature with micropyle and chorion discernible.

* Minety per cent or more or the ovaries observed contained primary follicles with abnormalities.

The reduction in the size of the adult ovary observed in this study is in agreement with that for house plies (Morgan and LeBrecque, 1962; and in press). The effects of chemosterilization on the egg chambers of house flles as observed by Morgan and IaBrecque showed a retardation in the development of the egg chambers and a reduction in the size of the ovary. 
In the author's study the ovary was decreased in size but the most signiflcant effects were seen in the nurse cells and the germarial regions. The germarium was partly or completely destroyed. This effect is consistent with that observed in the male. Ividently those eells within the follicle whlch have flnished the melotic divisions are capable of subsequent development at least to the extent of nurse cell Pormation. However, those cells wh1ch have not undergone melotic divisions or are in the process are partially or completely destroyed. This melotic destruction in treated Pemales parallels the effects in apholate-treated boll weev1ls observed by Iindquist et al. ( $1 \mathrm{n} \mathrm{ms.)} \mathrm{who} \mathrm{found} \mathrm{extremely} \mathrm{few} \mathrm{melotic} \mathrm{divisions} \mathrm{and} \mathrm{a} \mathrm{lack}$ of general organization in the me1ot1c stages. Ifndquist et al. (in ms.) postulated that apholate chemically interfered with the spermeogenlc transformations and/or melot1c II divisions. The latter effect appears to account for some of the germarial effects observed in this stuay. It is not known exactly what stages of melosis and mitosis are affected, if any, but there appears to be a definite atrophy of the germarial regions of the treated ovarles observed in this study. 


\section{SURMARY}

1. The orenge-pigmented, pear-shaped testes of 프. pusio adult males 11e dorso-laterally in the second to fourth abdominal segments. They are approximately 436 microns long and 168 mlcrons wlde.

2. The zone of transformation appears to occupy about 10 per cent of the length of the testis during the first doy, increasing at a descending rate of growth to approximately 72 per cent by the 12th day, and remains at approximately this percentage.

3. The vas deferens of the male is short and attaches to the ejaculatory duct next to the Iong, secretory accessory clands. The ejaculatory duct gradueliy nerrows as it reaches its polnt of attachment to the ninth segment.

4. The overies of H. pusio conta1n approximately 40 overloles and about half of these appear to develop at approximately the same rate. The spermathecae are somewhat atypical of that observed in other insects studied, in that they are colled ducts rather than hollow spheres and are without heavy sclerotization.

5. Sperm are trensferred from the spermathecae to the bursa in the female at the approximate time of egg deposition and are subsequently trensferred to the spermathecese after oviposition is completed. The mechanism by whlch this transfer occurs is not known. 
6. The mature sperm cells of $\mathrm{H}$. pusio males may be in the form of bundles or may occur singly and persist in both forms in the ferrele.

7. Both sexes of E. pusio undergo a sexual maturation following adult emergence, after which they are capable of nating. This development apparently requires the same time for both sexes and was found to be about 36 to 48 hours in this study.

8. Nales of E. pusio may mate wlth several femsles (up to four a dey).

9. Females of H. puslo are capable of laying an average of 26 eggs in an 18-day perlod. There is no apparent difference in the number of eggs laid by mated and unmated females although a slight dfference in the onset of oviposition indiceting a delay in oviposition by unated females was noted.

10. Both sexes of 프. puslo are capable of belng sterllized in the adult stage by feeding on lood treated with tepa, metepa, and apholste. Generally the concentration required to sterllize elther sex was Blightly higher than that concentration required to sterlilize both Bexes simultaneously. The female usually required a slightly higher concentration for sterility than the males.

11. The most apparent histological demage caused by the chemosterilants occurred in the germarial region of the gonads of both sexes. This region appeared to be elther completely or pertially destroyed in a 13-day period. Once development and differentiation of the sex cells had begun, it ald not appear to be stopped by the chemosterllants, but the sex cells were nevertheless rendered sterile.

12. The chemosterilants coused treated gnats to have ameller gonads then untreated gots. 


\section{IITHRATURE CIYED}

Abbott, W. S. 1925. A method of computing the effect1veness of an insect1c1de. J. Bcon. Bntomol. 18: 265-267.

Abrahran, R. 1934. Des Verhalten der Spermien der welblichen Bettwanze (C. lectularius L.) und der Verblelb der uberschussigen Spermesse. Z. Parasiten. 6: 559-591.

Abul-Nasr, 8. E. 1950. Structure and development of the reproductive system of some specles of Nematocera. Pht1. Trans. Roy. Soc. Iondon (B) 234: $339-396$.

Alexander, P. 1960. Radiation-1mitating chemicals. Sc1. Am. 202: 98-108.

Baumhover, A. H., Busman, C. N., Skspper, C. C., and New, W. D. 1959. Field observations on the effects of releasing sterlle screw-worms in Florida. J. Econ. Fntomol. 52: 1202-1206.

Bengston, Ida A. 1933. Seasonal acute conjunctivitis occuring in the southern states. Publ. Hinth. Repts. (U.s.) 48: 917-926.

Bertram, D. 8. 1959. The ovary and ovarioles of mosquitoes. "Course in edvanced entomological techniques applied to malaris eradication", WHO mineo pub. I. J. Bruce-Chwatt, Ea. 238: 170-180.

Blesele, J. J. 1958. M1totic polsons and the cancer problem. Elsevier Publ. Co., Nev York. 214 p.

Borkovec, A. B. 1962. Sexurl ster111zation of insects by chemicals. Science 137: 1034-1037.

Borkovec, A. B., and Woods, C. W. 1963. AzIridine chemosterilants. Sulfur-containing Azirldines. Adv. In Chean. Serles 41: 47-55.

Burden, G. S., and Sinttle, B. J. 1963. Chemosterllent studies with the German cockroach. Fla. Entomol. 46: 229-234.

Buxton, P. A. 1955. The natural h1story of tsetse flies. An account of the blology of the genus Glossins (Diptera). Iondon School Hyg. and Trop. Ned. Memoir No. I0. H. K. Lewls \& Co., Ltd. 816 p. 
Collehan, P. S., and Cascio, T. 1963. Histology of the reproductive trects and transmission of sperm in the corn ear worm, Hellothis zea. Ann. Intomol. Soc. Am. 56: 535-556.

Cantwell, G. E., and Henneberry, T. J. 1963. The effects of ganma. rediation and apholate on the reproductive tissues of Drosophila melanogaster Meigen. J. Insect. Path. 5: 251-264.

Chamberlain, W. F. 1962. Chemicel sterilization of the screw-worm. J. Econ. Entomol. 55: 240-248.

Christophers, S. R. 1911. The developnent of the egg follicle in Anophelines. Paludism. 2: 73-88.

Christophers, S. R. 1923. The structure and development of the female genttal organs and hypopygium of the mosquito. Ind. J. Med. Res. 10: 698-720.

Clayton, F. F. 1957. Absolute and relative frequences of spermatogenic stages at different pupel periods in prosophile virilis. J. Norph. 101: $457-476$.

Cressman, A. W. (In press) Response of citrus red mite to chemical sterilants. J. Dcon. Bntomol.

Crystal, M. M. 1963. The Induction of sexuel sterility in the screwworm Ply by antimetabolites and alkylating agents. J. Econ. Intomol. 56: 468-473.

Curtin, T. J., and Jones, J. C. 1961. The mechanism of ovulation and ov1position in Aedes aecypt1. Ann. Entomol. Soc. Am. 54: 298-313.

Devey, K. G. 1958. The migration of spernatozoa in the female of Phodnius prolixus, Stal. J. Exp. Biol. 35: 694-701.

Detinove, T. 8. 1962. Age-grouping methods in Diptera of medical importance. WHO monograph. $47.216 \mathrm{p}$.

Duncen, D. B. 1955. Nultiple range and multiple $F$ tests. Blometrics. 11: $1-42$.

Ephruss1, B., and Beadle, G. W. 1936. A transplantation techn1que for Drosoph11e. Am. Net. 70: 218-225.

Glaser, R. W. 1923. The effect of food on longevity and reproduction in flies. J. Exp. Zool. 38: 383-412.

Goldsulth, E. D., and Frank, I. 1952. Ster1lity in the female fruit Ily, Drosophila melonogaster, produced by the feeding of a follc acld entagonist. An. J. Physiol. 171: 726-727. 
Gouck, H. K., Crystal, M. M., Borizovec, A. B., and Melfert, D. W. 1963. A comparison of technlques for screenting chemosterilants of house flles and screw-worm flies. J. Econ. Fintomol. 56: 506-509.

Hal1, D. G. 1932. Some studies on the breeding media, development, and stages of the eye gnat, ㅍpㄹelates pus1o Loew. Am. J. Hyg. 16: $854-864$.

Harris, R. L. 1962. Chemical induction of sterility in the steble fly. J. Econ. Entomol. 55: 882-885.

Henneberry, T. J., Sintth, F. F., and McGovern, W. L. (In press) Some effects of gomma rediation and a chemosterilant on Mexican bean beetle. J. Econ. Bntanol.

Hewer, H. R. 1934. Studies in Zyerene. II. The mechan1sm of copulem tion and the passage of sperm in the femsle. Proc. Zool. Boc. Iondon. 2: 513-527.

Hodapp, C. J. 1960. The mechanim of terminalla rotation in male Aedes aespot1 (Iinnseus). M. S. Thesis. University of Maryland.

Hodapp, C. J., and Jones, J. C. 1961. The anatomy or the adult male reproductive system of Aedes eesypt1 (IInneeus) (Diptere, Culicidae). Ann. Entomol. Soc. Am. 54: 832-844.

Howerd, I. O., Dyar, H. G., and Krab, F. 1913. The mosquitoes of North and Central America end the Weat Indles. Vol. 1. A general consideration of mosquitoes, their habits, and their relations to the human species. Carnegle Inst. Washington Publ. 159. 520 p. (Deted 1912).

Jay, I. G. 1961. Laboratory and fleld studies on the ecology of B1ppelates pus10 Loew (Diptera: Chlorop1due) and related spec1es. M. S. Thesis. University of Florida. $84 \mathrm{p}$.

Jones, J. C. 1961. Observations on sexual1y depleted male Aedes aecrpt1 (L.). (Abstr.) An. Zool. 1: 362 .

KIng, R. C., Rubinson, Ann C., and Sintth, R. F. 1956. Obgenesis in adult Drosophila melanogester. Growth 20: 121-57.

Rnipling, E. F. 1955. Possibllities of insect control or eradication through the use of sexually sterile males. J. Econ. Intomol. 48: $459-462$.

Knipling, E. F. 1959. Sterlle male method of population control. science. 139: $902-904$. 
Kreuse, J. B. 1947. The development of the gonads of the wood-eating beetle, Passalus cormutus Fabriclus. Ann. Bntomol. Soc. Am. 40: $172-202$.

Kunm, H. W. 1935. The digestive mechanisu of one of the West Indien "eye gnats", 프ppelates pallipes Loew. Ann. Mrop. Med. Paresitol. 29: 283-302.

Kum, H. W., and Turner, T. B. 1936. The trangmission of yews from man to rabbits by an Insect vector, H1ppelates pallipes Ioew. Am. J. Irop. Med. 16: 245-263.

Lallecque, G. C. 1961. Studies with three alkylating agents as house Ily ster1lants. J. Econ. Fintomol. 54: $684-689$.

LeBrecque, G. C., Adcock, P. H., and Smith, C. I1. 1960. Tests with compounds affecting house Ily metabolism. J. Deon. Intomol. 53: $802-805$.

Labrecque, G. C., Melfert, D. W., and Gouck, H. K. 1963. Hefectiveness of three 2-methyl-azlridine derivatives as house fly chemosterilants. Fla. Intomol. 46: 7-10.

Lindquist, D. A., Carzysik1, L. J., Meyer, M. S., Scales, A. L., and Devich, T. B. (In ms.) Laboratory studies on sterilization of the boll weevil with apholste.

Litchfield, J. T., and Wilcoxon, I. 1949. A simplified method of evaluating dose-efiect experiments. J. Phermacol. and Bxp. Therapy. 96: $94-113$.

Lum, P. T. M. 1961a. The reproductive system of some Florlda mosquitoes. I. The male reproductive tract. Aan. Entonol. Soc. An. 54: 397-401.

Lun, P. T. M. 1961b. The reproduct1ve system of sone Florlan mosquitoes. II. The male accessory glands and their role. Ann. Entomol. Soc. An. $54: 430-433$.

Melfert, D. W., Fye, R. L., and LaBrecque, G. C. 1963. Fffect on house flies of exposure to residual applications of chemosterilents. Fla. Entomo1. $46(2)$ : 161-168.

Miller, A. 1950. The internal anstomy and histology of the imago of Drosophila melanogaster. p. 420-534. In "Blology of Drosophila", M. Demerec, Ed., John Wiley \& Sons, Inc., New York.

Nitlin, N., Butt, B. A., and Shortino, T. J. 1957. Befect of mitotic poisons on house fly oviposition. Physiol. Z0ol. 30: 133-136. 
Morgan, P. B., and LaBrecque, G. C. 1962. The effect of apholate on the ovarian development of house Plles. J. Bcon. Bntomol. 55: $626-628$.

Morgan, P. B., and LaBrecque, G. C. (In press) Bffect of tepa and metepa on overlan development of house flles. J. Econ. Bntomol.

Mulla, M. S. 1962. Vass rearing of three specles of Hippelates eye gnets (Diptere: Chlorop1dee). Ann. Intomol. Soc. An. 55: 253-258.

Murrey, W. S. 1963. The effect of apholate on the mosquito, Culex pipiens quinquefasciatus Sey. Ph.D. Thesis. University of Meryland. $75 \mathrm{~g}$.

Murvosh, C. M., Fye, R. L., end LeBrecque, G. C. (In press) Studfes on the mating behavior of the house Ply, Musca domestica I. Oh10 J. Sc1.

Murvosh, C. M., Iabrecque, G. C., and Smith, C. N. 1964. Bffect of three chenosterllants on house $21 y$ longevity and sterillty. J. Econ. Frntamol. 57: 69-93.

Nonidez, Jose F. 1920. The Internal phenomens of reproduction in Drosoph1la. B1ol. Bull. 39: 207-230.

Norris, Maud J. 1932. Contributions toward the study of Insect fertility. I. The general structure and operation of the reproductive orgens of the genera Bphest1a and Plod1a (Iepldoptera, Phycitidae). Proc. Zool. Soc. (no vol. no.) 595-611.

Omura, S. 1936. Studies on the reproductive system of the male of Bombyz mor1. I. Structure of the testis and the intretesticular behavior of the spermatozoa. J. Fac. Agr. Holkka1do Imp. Univ. Sepporo. 38: 151-181.

Omura, S. 1938e. Structure and function of the femsle genttal system of Bombyx morf with speciel reference to the mechanism of fertilization. J. Fac. Agr. Bolkaldo Imp. Univ. Sapporo. 40: $111-128$.

Omura, S. 1938b. Studies on the reproductive system of the male of Bombyx mor1. II. Post-testicular organs and post-testicular behavior of the spermatozoa. J. Fac. Agr. Holdseldo Imp. Undv. Sepporo. 40: 129-170.

Payme, M. A. 1933. The structure of the testis and movements of sperns in Chortophaga virldifasclate as demonstreted by Intravitem technique. J. Norph. 54: 321-346.

Ross, W. C. J. 1962. Blologlcal alkylating agents. Butterworth and Co., Itd., Iondon. $232 \mathrm{~g}$. 
Sanders, D. A. 1940. Musce domestica and Hilppelates flles; vectors of bovine mastitis. Science. 92: 286.

Schwartz, P. H., Jr. 1961. Behavlor of spermatozos of Aedes regypt1 (L.). K. S. Thesis. Univers1ty of Maryland. $45 \mathrm{p}$.

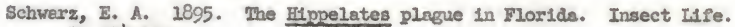
7: $374-379$.

Shaw, J. G., and Sanchez Riviello, M. 1962. Sterility in the Nexicen frult $\mathrm{Rly}$ ceused by chemicals. Sc1ence. 137: 754-755.

Snith, C. II., Lakrecque, G. C., and Borkovec, A. B. 1964. Insect chemoster1lants. Ann. Rev. Entomol. 9: 269-284.

Snedecor, G. W. 1961. Stat1st1cal methods applled to experiments in agriculture and blology. 5th ed. Iowe State Univ. Press, Ames, Iowa. $534 \mathrm{p}$.

Snodgrass, R. E. 1935. Principles of 1nsect morphology. McGraw-Hill Book Co., Inc., liew York. $667 \mathrm{p}$.

Snodgrass, R. R. 1956. The anatony of the honeybee. Comstock Publ. Assoc., Ithace, New York. $334 \mathrm{p}$.

Snodgrass, R. E. 1959. The anatomicel life of the mosquito. Smith. Miscell. Coll. 139(8): 1-87.

Stacey, K. A., Cobb, M., Cousens, S. F., and Alexcander, P. 1958. The reactions of the "radiomimetic" alkylating agents with micromolecules in vitro. Ann. N. Y. Acad. Sc1. 68: 682-701.

Stern, C. 1941. The growth of testes in Drosophils. I. The relation between vas deferens and testis within various specles. J. Bxp. Z001. 87: 113-158.

Tinmis, G. M. 1961. Antagonists of purine and pyrimialne metabolites and of folle acid. Adv. In Cancer Res, 6: 369-401.

Wessillef,, A. 1907. Die Spermetogenese von Blotte germanica. Arch. 1. Mikros. Anat. $70: 1-42$.

Weidhas, D. E. 1962. Chemical oterilization of mosquitoes. Nature. 195: $786-787$.

Weidheas, D. E., Ford, H. R., Gehen, J. B., and Smith, C. II. 1961. Preliminary observations on chenosterilization of mosquitoes. Proc. 48th Ann. 11. J. Мosq. Brterz. Assoc. p. 106-109.

We1dheas, D. E., and MeDuffie, W. C. 1963. Highllghts of recent research on chemosterilants for the control of insects of medical and veterinary importence. Bull. Ent. Soc. Am. 9: 268-272. 
West, L. S. 1951. The house fly, 1ts naturel history, medical importance, and control. Constock Publ. Assoc, Ithace, Mew Yoris.

Wheeler, R. I., and Jones, J. C. 1960. The mechanics of copulation in Aedes eesypti (L.) mosquitoes. (Abstr.) Anat. Rec. 138: 388.

Whelden, R. M., and Hnskins, C. P. 1953. Cytological and histologicel studies in the Formicidae. I. Chromosome morphology and the problem of sex determination. Ann. Entomol. Soc. An. 46: 579-595.

Wigglesworth, V. B. 1953. The principles of Insect physiology. E. R. Dutton and Co., Ine., New York. 546 p.

Woolley, D. W. 1952. A study of entinetabolites. John wiley and Sons, Inc., New York. $269 \mathrm{p}$.

Zacherulk, R. Y. 1958. Structures and Iunctions of the reproductive aystems of the pratrie grain wireworm, Ctenlcera eeripennis destructor (Brown) (Coleoptera: Elateridae). Caned. J. Z001. 36: $725-751$. 
BIOGRAPHICAL SKOTCH

Paul Henry Schwortz, Jr., was born December 19, 1936, at Beltinore, Maryland. He attended Catonsville Elementary and Junior Hifh School in Catonsville, Maryland, and was graduated from Howard. County Sentor High School in June, 1955. In June, 1959, he received. the degree of Bachelor of Sclence from the University of Maryland and In February, 1961, the degree of Master of Sclence from that institution. While at the University of Merylend he recelved a research fellowship and subsequently worked for six months for the State Experiment Station as a Blological Aid. He enrolled in the Graduate School of the University of Florida in February, 1961, and worked on a cooperative project between the University of Floride and the U. S. Department of Agriculture while pursuing the degree of Doctor of Philosophy.

Paul H. Schwartz, Jr., is married to the former Mary Frances Cox and is the father of two children. He is a member of the Entomological Society of America and the Florida Intomological Society and a member and past officer of Alpha Games Rho. 
Ihis dissertation was prepared under the drection of the chairman of the candidate's supervisory committee and has been approved by all members of that comittee. It was submitted to the Dean of the College of Agriculture and to the Graduate Counc11, and was approved. as partial fulfillment of the requirements for the degree of Doctar of Philosophy,

August 8, 1964.

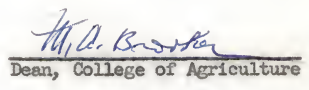

Dean, Greduate School

Supervisory Cormittee:

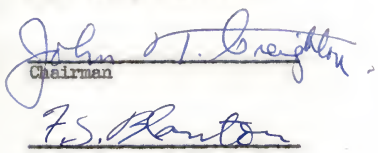

\section{Conal M. Lnith}

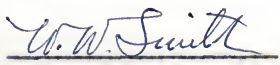

Q.tCaress 